\title{
PENAFSIRAN AL-ZAMAKHSYARI TERHADAP AYAT-AYAT MUTASYABIHAT DALAM TAFSIR AL-KASYSYAF.
}

\section{Sulkifli}

Sekolah Tinggi Agama Islam Negeri Majene

Email: sulkiflibanor@gmail.com

\begin{abstract}
Abstrak
Artikel ini membahas tentang penafsiran al-Zamakhsyari terhadap AyatAyat mutasyabihat dengan fokus pembahasan bertolak dari permasalahan pokok, yaitu pemikiran teologis al-Zamakhsyari terhadap ayat-ayat mutasyabihat dalam tafsir al-Kasysyaf. Hasil penelitian menunjukkan bahwa: (1) Ayat mutasyabih ialah ayat yang belum jelas atau samar penunjukannya. Kesamaran suatu ayat diakibatkan oleh beberapa hal, yaitu lafal, makna, dan dapat juga dari keduanya yakni lafal dan makna. (2) AlZamakhsyari mengakui eksistensi ayat-ayat mutasyabihat di dalam alQur'an. Disamping itu, al-Zamakhsyari mengakui pula kemampuan manusia memahami ayat-ayat mutasyabihat itu. (3) Al-Zamakhsyari menjelaskan makna sebagian huruf-huruf muqatt \{\} a'ah dan tidak sebagiannya. Ia menjelaskan makna sebagian ayat-ayat tajassum dan tidak menjelaskan sebagiannya.
\end{abstract}

Kata kunci: Penafsiran, ayat-ayat mutasyabihat, al-Kassyaf

\section{Pendahuluan}

Hal yang tidak terbantahkan lagi dalam dunia akademik ialah, bahwa hampir seluruh karya tulisan yang terdahulu hingga terkini dipengaruhi oleh kapan dan di mana tulisan itu ditulis. Hal tersebut memberikan dampak yang signifikan pada perbedaan cara pandang oleh setiap penulis yang berimplikasi pada setiap karya tulis yang mereka hasilkan. Pengaruh signifikan yang disebabkan sosial, budaya, dan latar belakang pendidikan penulis akan tampak pada karakter atau corak karya tulis yang dihasilkan para penulisnya, tidak terkecuali karya tulis dalam bidang tafsir.

Berbagai kitab tafsir yang dikenal mempunyai berbagai jenis corak tafsir. Corak tafsir tersebut memberikan identitas dan karakter tersendiri pada setiap tafsir yang mengemuka. Tafsir kalam misalnya -terfokus kajiannya terhadap ayat-ayat akidah sebagai objek pembahasan-, tafsir fikih -tafsir yang menjadikan ayat-ayat hukum sebagai objek pembahasan, misalnya hadis Nabi saw. yang memberikan penjelasan tentang keutamaan salat fajar dalam QS al-Isra'/17: 79-, Tafsir akhlak, tafsir yang memfokuskan perhatiannya pada 
ayat-ayat akhlak, misalnya tafsir Nabi saw. terhadap ungkapan lakanud dalam QS alAdiyat/100: 6 dengan "sangat ingkar", Tafsir adabi ijtimai -tafsir yang menjadikan ayat-ayat kemasyarakatan sebagai objek kajian tafsir-, tafsir ilmi -tafsir yang menjadikan ayat-ayat kauni sebagai objek pembahasan-, tafsir tibbi- tafsir yang membahas ayat-ayat terkait dengan penyembuhan penyakit-, tafsir sejarah/futurology -tafsir yang lebih fokus kajiannya pada ayat-ayat yang berkenaan dengan perjalanan hidup manusia maupun masa depannya-, dan yang terakhir adalah tafsir falsafi, yaitu tafsir yang membahas ayat-ayat berkaitan dengan filsafat. ${ }^{1}$

Sekian banyak corak tafsir yang penulis kemukakan di atas, corak tafsir yang terakhir mewarnai salah satu tafsir terkemuka pada abad XII M yaitu al-Kasysyaf karya alZamakhsyari. Karya tersebut menurut sebagian besar ulama berbentuk penafsiran bi-al$r a^{\prime} y i^{2}$. Penafsiran tersebut menurut Nasaruddin Baidan dikarenakan kaum teolog menafsirkannya dari sudut pemahaman teologis. ${ }^{3}$ Al-Juwaini menjelaskan hal-hal yang berkaitan dengan metode dan corak Tafsir al-Kasysyaf, diantaranya: (a) Setiap penafsirannya, akal manusia didahulukan dan dikuasakan, begitu juga al-sunnah, ijma', dan qiyas. AlZamakhsyari menjadikan akal sebagai alat bedah utama ketika menafsirkan dan memalingkan nas dalam keadaan terbuka dan tergali, mengingat ia tidak menerima nas dengan makna z\{ahirnya. (b) Al-Zamakhsyari menerapkan prinsip-prinsip Mu'tazilah dalam menafsirkan alQur'an. Hal tersebut tampak ketika ia menjadikan ayat-ayat yang mendukung Mu'tazilah sebagai ayat-ayat muhlkamat, sebaliknya jika ia menemukan ayat-ayat yang jelas bertentangan, maka dianggapnya mutasyabihat. (c) Al-Zamakhsyari terkadang menjadi mufassir naql. Dalam tafsirnya terkadang ia menggunakan Asbab al-Nuzul, Munasabah, Musnad, dan riwayat yang sampai kepada sahabat. Nasikh wa al-mansukh, baginya merupakan kaidah tafsir yang boleh bukan harus digunakan. ${ }^{4}$

Terlepas dari penilaian al-Juwaini terhadapnya, yang pastinya al-Zamakhsyari dalam menulis tafsirnya sangat dipengaruhi oleh mazhab teologi yang dianutnya, yang tampak pada corak tafsir al-Kasysyaf. Al-Zamakhsyari dalam memaknai ayat-ayat al-Qur'an sungguh terpengaruh oleh paham Mu'tazilah yang begitu rasional dan cenderung memalingkan makna zjahir ayat ke makna majazi demi mandapatkan makna yang relevan menurutnya, sebagimana pula para ulama-ulama Mu'tazilah yang lain ${ }^{5}$. Paham Mu'tazilah yang mempunyai lima konsep dasar atau Us\}ul al-khamsa (al- 'adl, al-tauhid, al-wa'd wa al-waid,

${ }^{1}$ Abd. Muin Salim, dkk, Metologi Penelitian Tafsir maudu'I (Makassar:Al-Zikra, 2011), h. 102-105.

${ }^{2}$ Perkembangan ilmu tafsir melahirkan dua bentuk tafsir, yaitu bi-al-matsur dan bi-al-ra'yi. Bi-alma's $\backslash u r$ ialah penafsiran dalam bentuk riwayat atau lebih dikenal dengan istilah tafsir bil ma's $\backslash u r$ atau bi alriwayat. Bentuk penafsiran ini lebih dominan menggunakan riwayat-riwayat dari Nabi sahabatnya ketimbang melakukan ijtihad. Sedangkan bentuk penafsiran bi-al-ra'yi bentuk penafsiran yang memberikan dominasi akal atau ijtihad dalam penafsirannya. Lihat Nasaruddin Baidan, Wawasan Baru Ilmu Tafsir.,h. 368-378.

${ }^{3}$ Nasruddin Baidan, Wawasan Baru Ilmu Tafsir (Cet I, Yogyakarta:Pustaka Pelajar, 2005), h. 376.

${ }^{4}$ Mustafa al-S \{awi al-Juwaini, Manhaj al-Zamakhsyari fi Tafsir al-Qur'an wa Bayan I'jazih ,[t.d.]., h. 163-191.

${ }^{5}$ Al-Jubbai misalnya dalam mempertahankan konsep al-adl-nya dia memahami surah al-An`am/6:112 yang membicarakan bagaimana Allah menjadikan musuh bagi setiap Nabi, baik dari setan maupun jin. Abu Ali al-Jubbai berargumen bahwa kata ja 'ala pada ayat tersebut (membuat) tidak hanya menunjukkan pada makna sana 'a (mencipta) namun juga bermakna "menjelaskan, menerangkan atau memberitahukan"dengan demikian makna ayat tersebut menurutnya "bahwa Allah menjelaskan pada seluruh nabi mengenai orang-orang yang menjadi musuh-musuhnya, agar mereka dapat melawannya di suatu waktu. Lihat Ignaz Golziher, Mazahibu alTafsir al-Islam, Terj. M.Alaika Salamullah, Mazhab Tafsir “dari Klasik hingga Modern” (Cet III, Yogyakarta: eLSPQ Press, 2006), h. 162. 
al-amru bi-al-ma'ruf wa-al-nahyu an-al munkar, al-manzilatu baina-al-manzilatain) dipahami oleh penulis menyebabkan al-Zamakhsyari begitu rasional. Ibnu Qutaiba berpandangan sebagaimana yang dikutip Golziher, orang-orang dari kaum Mu'tazilah yang mengambil sikap ekstrim menyerukan dengan lantang bahwa sesungguhnya buah dari produk rasionalitas itu menghasilkan pengetahuan dengan ma's $\backslash u r$. Sedangkan orang-orang dari golongan Mu'tazilah yang lebih moderat bersikap mendengar, yakni menonjolkan ketaatan dan bertangung jawab atas perintah-perintah syara' tanpa melihat pada sebab-sebab akal, tetapi melalui ukuran yang sama dengan ukuran akal. Al-Zamakhsyari menyatakan sependapat dengan dua mazhab di atas dengan dua metode untuk mengetahui agama. Metode tersebut membuatnya mampu (mengukuhkan) kebenaran mazhabnya dari al-Qur'an. Dia membangun argumentasinya dengan mengutip QS al-Mulk/69: 10, dimana pada ayat tersebut

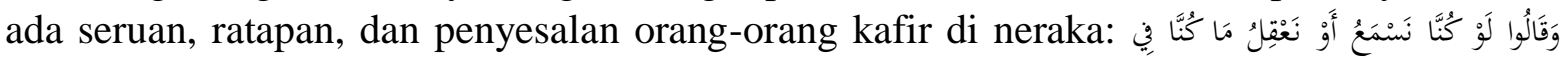
أَضْحَابِ السَّعِيرِ (andaikan kami mendengarkan (nasmau), atau kami berfikir (na'qilu), maka niscaya kami tidak akan masuk penghuni neraka). ${ }^{6} \mathrm{Al}$-Zamakhsyari ketika menafsirkan ayat al-Qur'an yang mendahulukan akal ketimbang riwayat-riwayat memunculkan reaksi dari para ulama-ulama yang kurang sepakat dengannya, salah satunya adalah Ahmad ibnu Munayyar yang menganggap bahwa hasil tafsiran al-Zamakhsyari merupakan elemen kemu'tazilahannya yang tersembunyi. ${ }^{7}$ Terlepas dari kritik tersebut, dengan menjadikan akal sebagai alat bedah utamanya, al-Zamakhsyari melakukan manuver penafsiran terhadap ayatayat mutasyabihat yang mana sebagian ulama tafsir masih berbeda pendapat tentang boleh tidaknya menafsirkan ayat-ayat tersebut. ${ }^{8}$ Bahkan lebih jauh lagi, al-Zamakhsyari menganggap bahwa sejak zaman azali Allah menghendaki adanya ayat-ayat yang sulit dipahami (mutasyabihat) agar manusia menjadikan ungkapan-ungkapan sulit tersebut wasilah untuk menguatkan iman, pengetahuan, dan mencari kebenaran. ${ }^{9}$

Keseriusan al-Zamakhsyari dalam memberikan penjelasan terhadap ayat-ayat mutasyabihat sebagaimana yang dikutip oleh Golziher tampak ketika ia berkata: jika kau mengatakan mengapa al-Qur'an tidak muh/kamat dan mengapa Allah menurunkan ungkapan-ungkapan yang dapat mengakibatkan keraguan dan mengandung makna yang bermacam-macam? Maka aku menjawab: kalau saja al-Qur'an itu seluruhnya muh $\} \mathrm{kam}$, tentu manusia akan bergantung kepadanya dengan kemudahannya, dan mereka tidak membutuhkan lagi yang namanya pengujian dan perenungan. ${ }^{10}$ Ignaz Golziher melihat bahwa penafsiran terhadap ayat-ayat mutasyabihat oleh al-Zamakhsyari tampak ketika dia menafsirkan QS al-A'raf/7: 172 "Dan ingatlah ketika Tuhanmu mengeluarkan anak-anak Adam dari sulbi mereka dan Allah mengambil kesaksian terhadap jiwa mereka (seraya berfirman) bukankah Aku Tuhanmu? Mereka menjawab:" betul (Engkau Tuhan kami), kami menjadi saksi". (kami lakukan demikian itu) agar di hari kiamat kamu tidak mengatakan: sesungguhnya kami (bani Adam) orang-orang yang lengah terhadap ini. (QS al-A'raf/7: 172)"11

\footnotetext{
${ }^{6}$ Ignas Golziher, Mazhab Tafsir.,h. 170.

${ }^{7}$ Ignas Golziher, Mazhab Tafsir., h. 158-159.

${ }^{8}$ Jalaluddin Abd al-Rahman al-Suyuti, al-Itqan fi Ulum al-Qur'an (Birut:Dar al-Kitab al-Arabi, 2010), h. 477.

${ }^{9}$ Ignas Golziher, Mazhab Tafsir., h. 161.

${ }^{10}$ Ignas Golziher, Mazhab Tafsir., h. 161.

${ }^{11}$ Kementerian Agama RI, Al-Qur'an dan Terjemahnya.
} 
Eksistensi al-Zamakhsyari dan pemikirannya dalam dunia tafsir memberikan warna yang berbeda pada kancah penafsiran al-Qur'an. keberanian dan kemampuan beliau menjelaskan ayat-ayat mutasyabihat yang memicu kontroversi di kalangan ulama dan akademisi menjadi hal yang menarik sekaligus pembeda dengan tulisan-tulisan sebelumnya. Hal tersebut mengilhami penulis untuk mengkaji lebih jauh hasil pemikirannya sekaligus mengangkat ke permukaan perbedaan yang substantif antara pemikiran al-Zamakhsyari yang rasional dengan mufasir yang lain. Oleh karena itu mengkaji mengkaji lebih mendalam dan konferehensif dalam bentuk penelitian ilmiah dengan fokus permasalahan tentang esensi ayat-ayat mutasyabihat, pandangan al-Zamakhsyari terhadap eksistensi ayat-ayat mutasyabihat dalam al-Qur'an, dan urgensi teologis penafsiran al-Zamakhsyari terhadap ayat-ayat mutasyabihat.

\section{Pembahasan}

Kata mutasyabih dalam bahasa Indonesia dapat diartikan "mirip" atau "samar-samar" juga mengandung berbagai konotasi yang biasanya membawa ketidak pastian atau ragu. Timbulnya keraguan tersebut ialah dikarenakan sangat miripnya dua benda yang diamati tersebut, sehingga tidak dapat, atau sulit sekali menentukan perbedaan yang satu dengan yang lain sebab keduanya sangat mirip. Kondisi inilah yang dijumpai dalam ayat-ayat al-Qur'an; saking miripnya ayat yang satu dengan yang lain, maka tidak dapat dibedakan antara masingmasing ayat itu karena semuanya berada pada level yang sama dari sudut balagah-nya, kemukjizatannya, kebenaran informasi yang dibawanya, penempatan kata yang akurat dan susunan kalimat-kalimat yang amat kokoh, dan sebagainya.

Dari pemaparan singkat tersebut dapat dipahami bahwa ayat-ayat mutasyabihat ialah ayatayat yang penunjukannya masih samar atau belum jelas. Kesamaran beberapa ayat dapat diakibatkan oleh lafal, makna, dan dapat pula diakibatkan oleh keduanya yaitu lafal dan makna sekaligus. Dari sisi lafalnya ketasyabuan suatu ayat terjadi karena terdapatnya kemiripan di dalamnya baik secara lafal maupun secara dilala yang mengakibatkan ketidak jelasan atau ketidak pastian makna yang terkandung didalamnya. Kesamaran dan ketidak jelasan maknanya suatu lafal dapat pula disebabkan oleh karena kosakata yang terdapat dalam suatu ayat sangat jarang digunakan oleh orang Arab (garib) seperti penggunaan kata wafakihatan waabba dalam surah 'Abasa/80: 31. Ketasyabuan dari sisi lafal dapat pula karena kosakatanya bersifat multiple sense (bermakna ganda) seperti penggunaan kata yamin dalam surah al-S\{affat/37:93 yang dapat bermakna tangan kanan dapat pula bermakna kekuatan. Adapun ayat-ayat yang tasyabuh seara makna yakni seluruh ayat yang menginformasikan mengenai berita-berita gaib seperti sifat-sifat Tuhan, malaikat, kondisi akhirat seumpama surga, neraka, hari kiamat dan sebagainya. Sedangkan ayat yang tasyabuh وليس البر بأن تأتوا البيوت 2ari sisi lafal dan makna sekaligus dapat dilihat pada surah al-Baqarah/2:189 (dan bukanlah kebaikan itu bahwa kamu memasuki rumah-rumah dari belakang). Ayat itu dianggap oleh ulama tasyabuh dari segi lafalnya dikarenakan ungkapannya terlalu padat, sedangkan ketasyabuhan dari maknanya terjadi karna ketidak pastian yang berkaitan dengan latar belakang turunnya ayat tersebut.

Lebih jauh, Para ulama tafsir sebenarnya mempunyai kesamaan pandangan mengenai eksistensi ayat-ayat mutasyabihat dalam al-Qur'an, hanya saja mereka berbeda dalam memberikan penjelasan. Sebagian dari ulama tafsir mencoba memberikan penjelasan mengenai ayat-ayat yang dianggapnya mutasyabihat dan sebagian yang lain lebih memilih mengembalikan pemaknaannya kepada Allah. Bagi ulama tafsir yang menafsirkan ayat yang dianggapnya tasyabuh merupakan suatu keistimewaan baginya, karena mereka menggunakan 
akal yang Allah berikan kepadanya. Sedangkan bagi ulama tafsir yang enggan menafsirkan ayat-ayat tasyabuh, adalah merupakan bentuk kehati-hatiannya. Selain itu, mereka lebih cenderung memahami bahwa di balik ketidak jelasan suatu ayat ada makna yang besar di baliknya. Lebih jauh, para ulama berbeda terkait dengan jumlah ayat-ayat mutasyabihat di dalam al-Qur'an. Husain bin Muhammad bin Hubaib al-Naisaburi membagi persoalan ini menjadi tiga hal. ${ }^{12}$ Pertama, seluruh ayat al-Qur'an muh\}kam dengan dalil QS Hud/11: الر. "kedua, seluruh ayat al-Qur'an mutasyabih dengan mengutip QS al-Zumar/39: 23. اللّ نزل احسن الحديث كتاب متشاهما مثاني "ketiga, al-Qur'an terdiri atas dua jenis ayat, yakni Muhjkamat wa Mutasyabihat dengan dalil QS Ali Imran/3: 7.

Selain kesamaan pandangan ulama tentang eksistensi ayat-ayat mutasyabihat, mereka pun sama menggap bahwa tidak ada sesuatu yang sia-sia dalam ciptaan Allah. Segala sesuatu yang Allah berikan kepada manusia tentunya mempunyai hikmah untuk kemaslahatan manusia. Hikmah-hikmah tersebut bisa saja kita temukan pada sesuatu yang sudah jelas maupun yang masih samar. Hal tersebut pula terjadi dalam al-Qur'an. Adanya ayat-ayat muh\}kam memudahkan manusia mengambil pelajaran dan petunjuk di dalamnya dalam menjalankan misi kekhalifahannya, namun sebaliknya adanya ayat-ayat mutasyabihat yang masih samar dan membutuhkan pena'wilan tentunya membawa hikma yang besar dibalik keberadaanya. Hikmah-hikmah tersebut dapat dilihat dalam beberapa hal, antara lain:

a) Memancing akal orang-orang beriman untuk selalu berfikir dan menganalisa. Akal yang jarang digunakan akan mati dan akan membuat pemiliknya bodoh dan cenderung selalu mencari yang mudah baginya. Kemudahan akan membuat manusia terlena dan jatuh pada kebodohan, sedangkan agama dikehendaki untuk memuliakan umat manusia. Namun, kemudahan ayat-ayat muh\}kamat tidak memberikan ruang pada akal untuk berfungsi secara maksimal. oleh sebab itu Allah menurunkan pula ayat-ayat mutasyabihat untuk memaksimalkan kinerja tersebut, Demikian menurut Muhammad Abduh. ${ }^{13}$

b) Menguatkan tentang kemukjizatan al-Qur'an, karena sesungguhnya setiap apa yang memerlukan di dalamnya sesuatu yang menuntun kepada kesamaran terdapat keagungan dan kesempurnaan disisi balagahnya. ${ }^{14}$

c) Memberikan kemudahan kepada manusia dalam menghafal dan menaati (perintah) alQur'an. Sesungguhnya apa yang terkandung dari pengertiannya yang harus tertutup (samar) tersebut, menunjukkan adanya makna-makna yang banyak atas apa yang diperoleh dari sumber kalam (perkataan). Sekiranya disampaikan al-Qur'an (kalam) ini dari makna-makna yang lain dengan beberapa lafal, maka tentunya al-Qur'an akan keluar dengan berjilid-jilid yang besar, dan itu mustahil menghafalnya dan menaatinya sebagaimana dalam QS al-Kahf/18: 109 "Katakanlah (Muhammad) seandainya lautan menjadi tinta untuk (menulis) kalimat-kalimat Tuhannmu, maka pastilah habis lautan itu sebelum selesai (penulisan) kalimat-kalimat Tuhanku, meskipun kami datangkan tambahan sebanyak itu pula". ${ }^{15}$

d) Di mana terdapat ayat-ayat mutasyabihat maka di situ terdapat akses kepada kebenaran yang lebih sulit. Tambahan kesulitan mengharuskan adanya tambahan pahala.

${ }^{12}$ Badruddin Muhammad bin Abdullah Al-Zarkasyi, al-Burhan fi ulumil Qur'an, h. 79.

${ }^{13}$ Muhammad Rasyid bin 'Ali Rid\}a, Tafsir al-Qur'an al-Hakim:Tafsir al-Manar, Juz III (Cet. I, Berut:Dar al-Fikr, 2007),h. 120.

${ }^{14}$ Al-Zarqani, Manahil al-Irfan fi Ulum al-Qur'an, Juz II. h. 325.

${ }^{15}$ Al-Zarqani, Manahil al-Irfan fi Ulum al-Qur'an, Juz II. h. 326 
Sebagaimana firman Allah dalam QS A<li 'Imran/3: 142 “Apakah kamu mengira bahwa kamu akan masuk surga, padahal belum nyata bagi Allah orang-orang yang berjihad di antara kamu, dan belum nyata orang-orang yang sabar”. Demikian menurut Fakh alRazi yang dikutip oleh al-Zarqani. ${ }^{16}$

e) Fakh al-Razi juga berkata bahwa dengan terkandungnya muh\}kam dan mutasyabih dalam al-Qur'an, memaksa atau mengharuskan orang yang melihat di dalamnya (alQur'an) melihat sekumpulan pengetahuan yang banyak. Seperti Nahwu, Ushul fikh dari apa yang menyebabkan pandangan dan argumentasi. Menurutnya, keberadaan ayat-ayat mutasyabihat menjadi sebab-sebab pada kumpulan pengetahuan yang banyak. ${ }^{17}$

f) Dengan terkandungnya muh\}kam dan mutasyabih dalam al-Qur'an, memaksa atau mengharuskan orang yang melihat di dalamnya (al-Qur'an) meminta bantuan akalnya, dan menjauhi kesesatan taklid. Maksud semua itu untuk kepentingan akal. Sekiranya semua ayat al-Qur'an itu muh\}kam dimana lagi membutuhkan petunjuk-petunjuk akal, dan ayat-ayat mutasyabihat tersebut menghidupkan atau melanjutkan

kerja akal yang telah dilalaikan. ${ }^{18}$

g) Mengindikasikan kepada manusia akan adanya sesuatu yang jelas (tampak) dan kurang jelas (samar) atas ciptaan Allah dan kesemuanya mesti diimani oleh manusia sebagimana dalam QS Al-Baqarah/2: 2-3; “kitab al-Qur'an ini tidak ada keraguan padanya; petunjuk bagi orang-orang yang bertaqwa. yaitu mereka yang beriman kepada yang gaib”.

Dari beberapa ulama tafsir di atas, seorang ulama tafsir yang yang cukup pupuler bernama Al-Zamakhsyari sempat menghebohkan dunia penafsiran. Dia sendiri sebagai ulama Tafsir mengakui eksistensi ayat-ayat mutasyabihat dan berani menjelaskan makna yang sebagian besar ulama enggan menjelaskannya. Pengakuan beliau tentang keberadaan ayat-ayat Mutasyabihat dapat dilihat secara jelas ketika ia kemukakan dalam mukaddimah tafsirnya. Ia memulai tafsirnya dengan pujian kepada Allah yang telah menurunkan al-Qur'an dengan dua bagian atau bentuk, yakni muh \}kam dan mutasyabih, sebagaimana dalam pernyataanya;

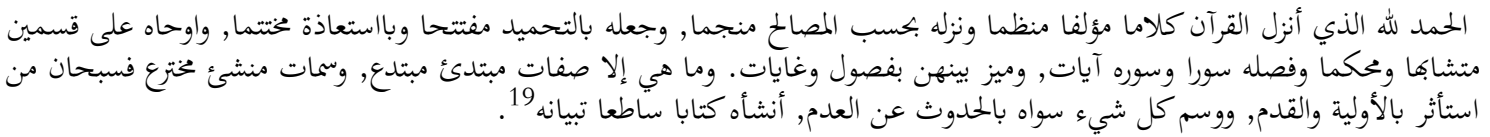

"Segala puji hanya kepada Allah yang telah menurunkan al-Qur'an yang merupakan kalam (perkataan) yang tersusun dan sistematis, dan menurunkannya dengan pertimbangan kemaslahatan yang merupakan jalan terang, dan menjadikannya dengan pujian yang terbuka dan dengan perlindungan yang lengkap, dan mewahyukan alQur'an dengan dua bagian yaitu muh kkam dan mutasyabih kemudian merincinya dengan surah kemudian membatasinya dengan ayat-ayat, lalu membedakan antara ayatayat tersebut dengan beberapa bagian dan tujuan. Tidaklah itu melainkan ciri-ciri yang dimulai dari sesuatu yang sebelumnya tidak pernah ada, dan ciri-ciri pencipta Mahasuci (Allah) yang kekuasaan dan ke qadimanNya tidak diragukan, Ia (Allah) menandai tiaptiap sesuatu dengan ketidak abadian selain-Nya, Ia (Allah) menjadikan suatu kitab yang jelas penjelasannya.

${ }^{16}$ Al-Zarqani, Manahil al-Irfan fi Ulum al- Qur'an, Juz II. h. 326.

${ }^{17}$ Al-Zarqani, Manahil al-Irfan fi Ulum al-Qur'an, Juz II. h. 326.

${ }^{18}$ Al-Zarqani, Manahil al-Irfan fi Ulum al- Qur'an, Juz II. h. 326-327.

${ }^{19}$ Al-Zamakhsyari, al-Kasysyaf an Haqaiki al-Tanzili wa 'Uyuni al-Ta'wili fi Wujuh al-Ta'wil, Juz I ( Kairo:Dar al-Hadis, 2012), h. 15. 
Al-Zamakhsyari dalam menjelaskan eksistensi ayat-ayat mutasyabihat tidak memberikan komentar panjang lebar sebagaimana ulama-ulama tafsir yang lain ketika menjelaskan eksistensi ayat mutasyabihat. ${ }^{20}$ Dalam penjelasanya, ia tidak menggunakan satupun riwayat untuk mendukung argumentasinya. Al-Zamakhsyari tampaknya tidak ingin terlibat dalam perdebatan dengan menggunakan riwayat sebagai acuan argumentasi mereka, baik yang pro maupun yang kontra. Sikap tersebut tampak ketika menjelaskan kata al-muh\}kamat dan almutasyabihat dalam QS Ali 'Imran/3: 7, هو الذى أنزل عليك الكتاب منه Tيات محكمات هن أم الكتاب وأخر متشاجهات berikut ini penjelasannya:

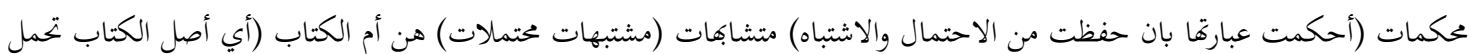

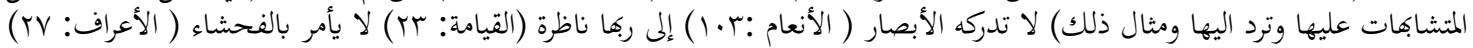

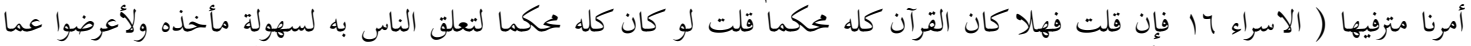

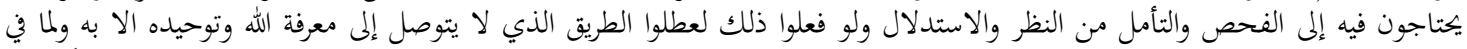

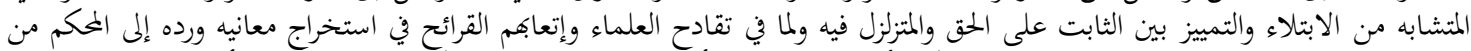

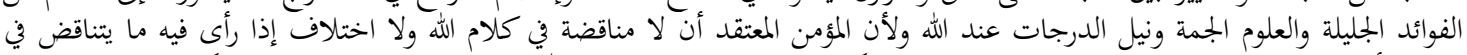

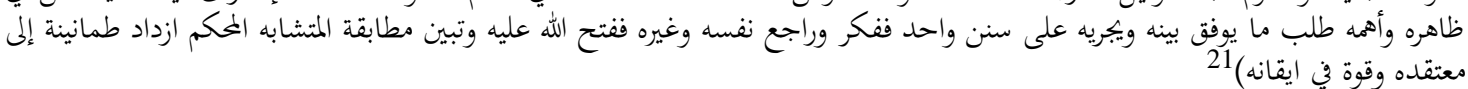

Mutasyabih menurut al-Zamakhsyari bermakna serupa dan mengandung kemungkinan. Keserupaan yang ada pada suatu lafal memungkinkan diartikan atau dipahami dengan beragam. Kemungkinan pemahaman dan pemaknaan yang beragam tersebut bisa saja lahir dari satu lafal dimana pada saat tertentu digunakan dengan makna umum namun di tempat terpisah digunakan dengan makna khusus. Dengan melihat pemaparan al-Zamakhsyari di atas tampak bahwa ia lebih memilih mengemukakan tentang kemampuan manusia memahami ayat yang tasyabuh. Baginya Allah akan menyingkapkan makna yang samar bagi orangorang yang bersungguh-sungguh ingin memahami makna di balik kesamaran satu ayat. Pernyataan tersebut cukup beralasan karena tidaklah mungkin Allah menciptakan sesuatu dengan sia-sia, sedangkan menurut al-Zamaksyari ayat-ayat yang tasyabuh mengandung keutamaan-keutamaan bagi umat manusia. ${ }^{22}$

Penjelasan al-Zamakhsyari tampak lebih memilih mengemukakan keutamaan orang-orang yang bersungguh-sungguh mencari makna dibalik ayat mutasyabihat ketimbang terlibat dalam perdebatan antara boleh tidaknya mena'wilkan ayat-ayat al-Qur'an dengan mengggunakan beberapa riwayat. Kendati demikian, tidak bisa dipungkiri bahwa beliau adalah salah satu yang termasuk pendukung utama kaum rasionalis yang memberikan peluang lebih banyak kepada akal untuk memahami ayat-ayat yang masih samar penunjukannya. Baginya, mengungkap makna ayat-ayat mutasyabihat adalah jalan untuk mendapatkan ketenangan hati dan akan mengukuhkan pendirian seseorang, dan hal tersebut lebih baik dari pada hanya mengarahkan semua perhatian pada ayat-ayat muh\}kam yang penunjukannya lebih mudah dan jelas.

Al-Zamakhsyari secara tidak langsung mengkritisi para ulama maupun orang-orang yang selalu bergantung pada makna ayat-ayat muh\}kam. Bagi al-Zamakhsyari hal yang seperti itu

\footnotetext{
${ }^{20}$ Dalam beberapa kitab tafsir ditemukan beberapa ulama mengemukakan beberapa riwayat dan pendapat mengenai ayat-ayat mutasyabihat. Pendapat-pendapat tersebut seringkali tidak menampakkan pendapat mereka karena lebih terjebak mengemukakan pendapat-pendapat ulama sebelumnya atau riwayatriwayat baik yang mendukung maupun yang menolak. Lihat misalnya Ibn Kaslir, Tafsir al-Qur'an al- 'Az\}im, h. 326, al-Qurtubi, Jami al-Ahkam al-Qur'an, h. 8.

${ }^{21}$ Al-Zamakhsyari, al-Kasysyaf, Juz I, h. 316.

${ }^{22} \mathrm{Al}$-Zamakhsyari, al-Kasysyaf, h. 316.
} 
akan semakin memanjakan manusia atas kemudahannya dan membiarkan mereka tetap berada dalam ketidak jelasan. Lebih lanjut, kritik beliau seakan mengatakan bahwa mencari makna apa yang belum jelas (tasyabuh) lebih mulia dari pada menyandarkan segala pemaknaanya pada Allah. Kemampuan memahami ayat-ayat tersebut baginya bisa dipahami oleh orang-orang yang mendalam ilmunya.

Bagi al-Zamakhsyari makna ayat-ayat mutasyabihat dominan hanya dipahami oleh Allah, namun bukan berarti orang-orang tertentu tidak mendapatkan peluang untuk dapat memahami makna ayat-ayat mutasyabihat tersebut. Mereka adalah orang-orang yang mendalam ilmunya dengan pengamatan dan ketekunan yang tinggi. Hal tersebut cukup mendasar dengan menjadikannya kata al-rasikhuna fi al-'ilmi sebagai ma't\} uf kepada harfu jalalah yang terletak sebelumnya dan kata yakuluna merupakan hal-nya. Dari susunan kata tersebut dapat diartiakan secara sederhana "tidak ada yang mengtahui ta'wilnya kecuali Allah dan orangorang yang mendalam ilmunya dan mereka berkata kami beriman/mengimani ayat mutasyabih dan semuanya ini dari sisi Tuhan kami baik yang muh\}kam maupun mutasyabih". Lebih lanjut, untuk mendukung argumentasinya, al-Zamakhsyari menjelaskan lanjutan ayat di atas وما يذكر إلا أولوا الألباب (tidak ada yang dapat mengambil pelajaran kecuali orang yang berakal), baginya ayat tersebut merupakan pujian terhadap (al-rasikhun) orangorang yang mendalam ilmunya atas kecerdasan dan perhatiannya yang baik. Penjelasan tersebut sangat kental nuansanya untuk mengiyakan bahwa orang-orang yang mendalam ilmunya diberikan wewenang untuk mena'wilkan ayat-ayat yang tasyabuh.

Secara sederhana, dalam menentukan ayat-ayat mutasyabihat, hampir tidak ditemukan standarisasi yang digunakan oleh al-Zamakhsyari dalam menentukan ayat-ayat tersebut, namun untuk mengidentifikasi mana ayat-ayat mutasyabihat menurut al-Zamakhsyari, dapat kita lihat dalam pernyataannya ketika mengomentari QS A $<$ li 'Imran/3: 7. Dalam penjelasannya ia mengemukakan beberapa contoh ayat-ayat mutasyabihat dalam al-Qur'an seperti QS al-Qiyamah/75: 23, QS al-An'am/6: 103, QS al-A'raf/7: 28, dan QS al-Isra/17: 16. Hal yang serupa bisa kita dapatkan dalam penafsiran beliau terhadap beberapa huruf-huruf muqat\}t\}a'ah pada awal surah dan beberapa ayat-ayat tajassum.

\section{Penafsiran Al-Zamakhsyari Terhadap Huruf-Huruf Muqat\}t \}a'ah}

Interpretasi al-Zamakhsyari terkait makna huruf al-Muqat\}t\}a'ah yang terdapat pada dua puluh sembilan awal surah. Huruf-huruf tersebut penulis bagi menjadi beberapa kelompok ayat.

a. Awal surah yang menggunakan kata litemukan sebanyak enam surah yaitu; QS alBaqarah, QS A < li 'Imran, QS al-Ankabut, QS al-Rum, QS Luqman, QS al-Sajadah.

Al-Zamakhsyari berpandangan mengenai huruf-huruf tersebut sebagai huruf yang mabsut\}ah (terbuka, membentang) huruf dimana satu kata disusun, sebagimana ketika kita berkata dad satu nama yang dipanggil dengannya dengan kata dah yang terjadi akibat perubahan kata ketika mengeja, demikian pula menurutnya ketika kita berkata $r a$ dan $b a h$ itu adalah dua nama, sama ketika kita berkata rah, bah. Susunan kata-kata tersebut merupakan penamaan yang sungguh lembut. Menurutnya, kata alif lam mim pada awal surah tersebut menyerupai lafal permohonan yang menunjukkan makna التهليل(tahlil), والحوقلة(ucapan lahaula wala kuwata), والحيعل (ucapan hayya 'ala), dan basmalah). Lebih jauh, alZamakhsyari memahami bahwa potongan huruf-huruf tersebut yang terdiri dari I (alif), J (lam), dan ( $\mathrm{mim}$ ) pada awal QS al-Baqarah dan lima surah yang lain merupakan tempat 
berhenti sebagaiman ketika kita berkata satu, dua, dan tiga. Hal itu bisa dilihat dalam pernyataanya:

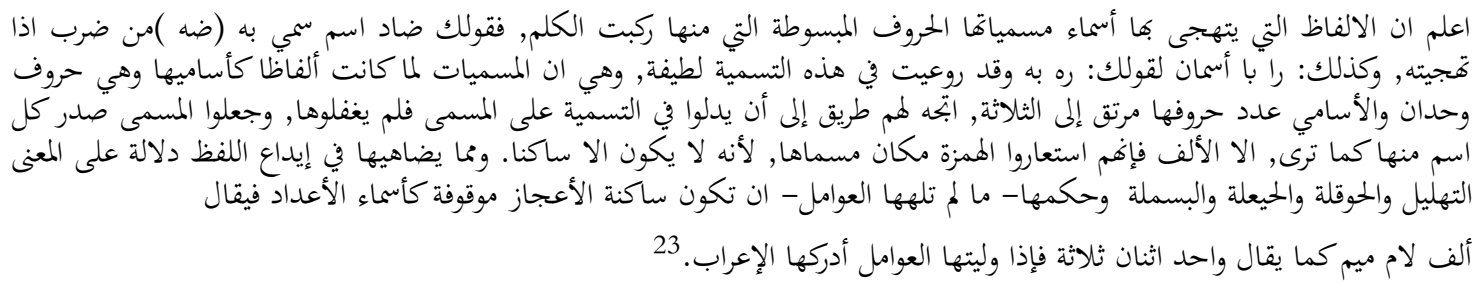

"ketahuilah bahwa sesungguhnya lafal-lafal yang disusun dengannya adalah nama-nama yang dinamai huruf mabsutah yang darinya disusun suatu perkataan, sebagai mana ketika engkau berkata $d a d$ adalah satu nama yang dipanggail dengan kata $d a h$ yang terjadi dari perubahan kata ketika [pembicara] mengejanya. Demikian pula kata $r a$ dan $b a$ adalah dua nama sebagaimana ketika kita berkata $r a h, b a h$. Tampak Penamaaan tersebut sangat lembut. hal itu terjadi mengingat nama-nama tersebut merupakan lafal yang unik dan melembutkan jumlah hurufnya yang terbentuk menjadi tiga huruf. Semua huruf tersebut menunjukkan suatu penamaan yang tidak terlewatkan. Dan mereka menjadikan hal tersebut permulaan atau bagian awal pada tiap-tiap nama darinya, sebagaimana yang kamu lihat, Kecuali alif karena sesungguhnya mereka hanya meminjam hamsah pada tempat yang dinamainya. Sesungguhnya huruf tersebut tidak terjadi kecuali dengan sukun. Dan dari kata tersebut seperti satu ucapan permohonan tahlil, al-haukalah (la haula wala kuwwata illah biillah), al-hayya 'alah (hayya 'ala shalat), basmalah (bismillahi rahmani rahim), ..., huruf merupakan huruf sukun yang ditempati berhenti seperti ketika berkata satu, dua, dan tiga.

Ketika ia menjelaskan huruf-huruf tersebut ia hanya menjelaskan secara umum, mengenai makna kata alif lam mim yang terdapat pada QS al-Baqarah. Penjelasan yang sama ketka menjelaskan QS A<li Imran/3: 1. Hanya saja ia berkata bahwa huruf mim pada kata alif lam mim sebenarnya merupakan wakaf (tempat berhenti) untuk memulai setelahnya sama berhentinya pada alif dan lam. Huruf tersebut seperti ketika kita berkata satu dua tiga untuk

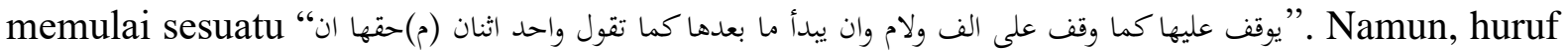
yang sama dalam beberapa surah yang lain tidak ditemukan penjelasannya mengenai hurufhuruf tersebut. Tidak adanya penjelasan al-Zamakhsyari mengenai huruf tersebut selain yang terdapat pada QS al-Baqarah dan QS Ali 'Imran memungkinkan dengan dua hal. Pertama, ia menganggap bahwa huruf-huruf tersebut sudah terwakili penjelasan ketika menjelaskan QS al-Baqarah, kedua, ia mengangngap huruf-huruf tersebut mempunyai makna yang sama antara satu dengan yang lain.

b. Awal surah yang mengggunakan kata الر ditemukan pada lima surah yakni pada surah QS Yunus, QS Hud, QS Yusuf, QS al-Hijr, QS Ibrahim.

Dalam penjelasannya, al-Zamakhsyari berpandangan mengenai huruf alif lam ra pada surah Yunus sebagai تعديد للحروف على طريق التحدي bilangan huruf yang mengarah atau menunjukkan satu tantangan atau huruf-huruf yang menantang. Adapun pada empat surah lainnya, tidak ditemukan penjelasannya mengenai kata tersebut.

${ }^{23} \mathrm{Al}-Z a m a k h s y a r i$, al-Kasysyaf an Haqaiki al-Tanzili wa Uyun al-Ta'wili Fi Wujuh al-Ta'wili, Juz I ( Kairo:Dar al-Hadis, 2012), h. 36. 
c. Awal surah yang menggunakan kata $\sim$ ditemukan sebanyak tujuh kali, kata ha mim disebut sebagai kelompok hawamin yaitu surah surah yang dimulai dengan huruf ha dan mim, ketujuh surah tersebut ialah; QS Gafir, QS Fussilat, QS al-Syurah, QS al-Zukhruf, QS al-Dukhan, QS al-Jaziyah, QS al-Ahqaf. Adapun makna huruf-huruf potongan tersebut tidak dijelaskan oleh al-Zamakhsyari.

d. Awal surah yang menggunakan kata bسم ditemukan sebanyak dua kali, yakni pada QS alSyu'ara, dan QS al-Qasas. Huruf-huruf potongan tersebut tidak dijelaskan olehnya.

e. Awal surah yang menggunakan kata bس ditemukan penggunaannya hanya satu kali, yakni pada QS al-Naml dan tidak dijelaskan oleh al-Zamakhsyari.

f. Awal surah yang menggunakan kata المر ditemukan hanya sekali yakni pada QS al-Rad, huruf tersebut tidak dijelaskan oleh al-Zamakhsyari.

g. Awal surah yang menggunakan dua huruf muqat\}t; $a^{\prime} a h$ dan sekaligus menjadi nama surahnya ada dua, yaitu kata طه ditemukan hanya satu kali saja, yakni pada QS T \{ aha dan disebutkan hanya sekali saja yakni pada QS Yasin.

Kata t\{a ha menurut al-Zamakhsyari bermakna ya rajulun, إن ( طاها ) في لغة عك في معنى يا رجل sesungguhnya kata t\}a ha dalam bahasa ditafsirkan dengan "wahai seorang laki-laki". Dan boleh jadi menurutnya merupakan kata gantian dari kata ya hazla, dimana kata $t$ \}a merupakan gantian dari kata ya dan huruf ha merupakan gantian dari hazla ${ }^{24}$. Berikut pernyataannya:

إن ( طاها ) في لغة عك في معنى يا رجل ، ولعل عكا تصرفوا في ( يا هذا ) كأفم في لغتهم قالبون الياء طاء ، فقالوا في ( يا ) : ( طا ) )

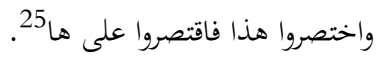

Dengan demikian ayat satu dua dalam surah $\mathrm{T}$ \{aha bisa diartikan "wahai seorang lelaki, kami tidak menurunkan al-Qur'an ini kepadamu agar engkau menjadi susah", atau "wahai seorang lelaki (Muhammad), ini al-Qur'an tidak diturunkan kepadamu agar engkau menjadi susah". Sedangkan kata ya sin merupakan bahasa T\{a'i, dan menurutnya bermakna ya ayyuha al-insan (wahai manusia (Muhammad)-. Pandangan tersebut dikutipnya dari Ibn Abbas. Menurutnya kata tersebut sebenarnya bersal dari kata يا أنيسين ( ya an yasin). ${ }^{26}$ hal itu bisa dilihat pada pernyataanya:

$$
\text { وعن ابن عباس رضي الله عنهما: معناه يا إنسان في لغة طيى، والله أعلم بصحته، وإن صح فوجهه أن يكون أصله يا أنيسين } 27 \text { إن. }
$$

"Dari Ibn Abbas ra. Maknanya wahai manusia dalam bahasa T\{a'i, Allah lebih mengetahui kebenarannya, dan sesungguhnya pengertian yang tepat ialah berasal dari kata ya ayyasin".

Dari penafsiranya tersebut maka dapat diterjemahkan QS Yasin ayat satu dan dua dengan makna "wahai manusia (Muhammad), demi al-Qur'an yang penuh dengan hikmah". Pendapat tersebut disandarkanya kepada Ibn Abbas namun tampak al-Zamakhsyari tidak punya cukup alasan untuk mendukung argumentasinya dan terkesan memaksakan penjelsan huruf-huruf tersebut baik pada surah $\mathrm{T}\{$ aha maupun surah Yasin. Hanya saja ketika ia melakukan

\footnotetext{
${ }^{24} \mathrm{Al}$-Zamakhsyari, al-Kasysyaf, Juz III, h. 46.

${ }^{25}$ Al-Zamakhsyari, al-Kasysyaf, Juz III, h. 45.

${ }^{26} \mathrm{Al}-$ Zamakhsyari, al-Kasysyaf, Juz III, h. 573.

${ }^{27}$ Al-Zamakhsyari, al-Kasysyaf, Juz III, h. 573.
} 
penjelasan pada huruf tersebut, ia tetap mengembalikan kebenaran mutlaknya hanya diketahui oleh Allah dengan berkata الله اعلم بصحته (Allah lebih mengetahui kebenarannya).

h. Awal surah yang menggunakan المص digunakan hanya sekali, yaitu pada QS al-A'raf. Huruf muqat $t_{t}{ }^{\prime} a$ 'ah tersebut tidak mendapatkan penjelasan oleh al-Zamakhsyari.

i. Awal surah yang menggunakan kata كهيe digunakan hanya sekali, yaitu pada QS Maryam. Huruf-huruf tersebut tidak dijelaskannya melainkan hanya mengutarakan cara membacanya.

j. Awal surah yang menggunakan hanya satu kata yang sekaligus menjadi nama surahnya ditemukan sebanyak dua kali yakni huruf a qaf pada QS Qaf, dan huruf ص pada QS S\{ad. huruf qaf dalam surah Qaf tidak mendapatkan penjelasan dari al-Zamakhsyari mengenai maknanya. Sedangkan huruf $s\} a d$ dipahami oleh al-Zamakhsyari dengan dua pandangan, pertama huruf tersebut adalah huruf hijaiyyah yang berfungsi sebagai tahaddi (tantangan) dan tanbih (peringatan). Kedua, merupakan isyarat yang menunjukkan makna صورة (surah) yang merupakan khabar dari hazlihi yang mahz\uf. Oleh sebab itu menurut al-Zamakhsyari, ayat tersebut bisa dimaknai "ini surah melemahkan orang Arab, demi al-Qur'an yang mengandung peringatan". Berikut penjelasan beliau:

فيه وجهان ، أحدهما : أن يكون قد ذكر اسم هذا الحرف من حروف المعجم على سبيل التحدّي والتنبيه على الإعجاز كما مرّ في أوّل

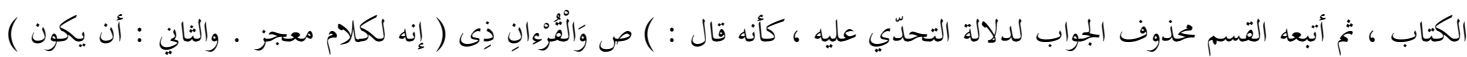

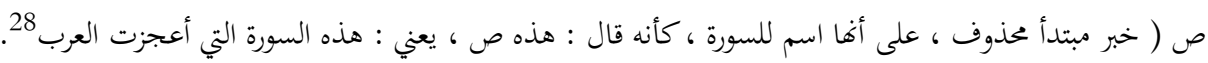

"( $\{\{a d)$ Mempunyai dua pengertian, pertama; s\}ad merupakan bagian dari abjad dengan tujuan tahaddi (tantangan) dan tanbih (peringatan) atas suatu kemukjizatan (alQur'an) sebagaimana yang terdapat pada permulaan kitab (QS al-Baqarah), kemudian ia mengikutinya dengan sumpah yang dihilangkan jawabannya (مخوف الجواب) dengan tujuan sebagai tantangan. Kedua; ,..., s\}ad merupakan isyarat nama surah dan seakan berkata ini surah yang melemahkan atau melumpuhkan orang-orang Arab".

k. Awal surah yang menggunakan satu kata namun bukan menjadi nama surahnya disebutkan hanya sekali yaitu kata ن yang terdapat pada awal QS al-Qalam.

Al-Zamakhsyari dalam menjelaskan huruf tersebut mengutip pada suatu argumentasi yang tidak disebutkannya secara jelas. Kata nun sebagaimana yang dia kutip pada awal surah alQalam merupakan tempat tinta, namun menurutnya tempat tersebut tidak dipahaminya apakah itu bermakna secara bahasa atau secara syar'i. Menurut al-Zamakhsyari huruf tersebut tidaklah melanggar apabila betul bahwa kata nun pada ayat tersebut merupakan satu nama untuk tempat tinta, baik itu suatu jenis benda atau satu tanda. Namun menurutnya, apabila itu adalah betul satu jenis benda (tempat tinta) dimana tanwinnya -sebagai tanda dari isim-, dan jika itu suatu tanda maka mana i'rabnya?. Dan jika Keduanya (tempat tinta atau hanya tanda) menurut al-Zamakhsyari wajib mendapatkan tempat dalam penyusunan kata. ${ }^{29}$ Dengan hal tersebut, al-Zamakhsyari tampak lebih condong memahami huruf tersebut sebagai huruf sumpah dengan maksud menantang sedangkan kata kalam yang ada setelahnya merupakan pengaguman atas ciptaan dan penyelesaian-Nya atas ciptan tersebut, hal itu bisa dilihat dalam penjelasannya:

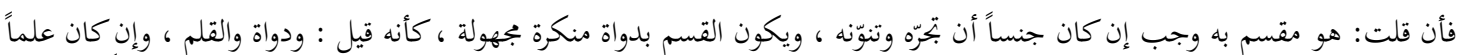

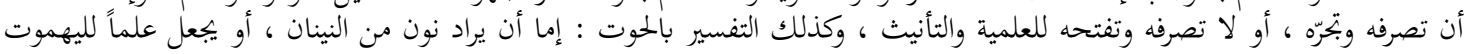

\footnotetext{
${ }^{28}$ Al-Zamakhsyari, al-Kasysyaf, Juz IV, h. 233.

${ }^{29} \mathrm{Al}$-Zamakhsyari, al-Kasysyaf, Juz IV, h. 435.
} 
على الحكممة العظيمة30 ، والتسير باللوح من نور أو ذهب ، والنهر في الجنة نحو ذلك ، وأقسم بالقلم : تعظيماً له ، لما في خلقه وتسويته من الدلالة

“jika kamu berkata: huruf tersebut disumpahkan maka wajib jika huruf itu menunjuk kepada suatu jenis (benda) mendapatkan tanda jar dan tanwinnya, dan adapun sumpah dengan tinta (dawat) yang tidak diketahui (majhul), seakan dikatakan: wadawat wa alqalam (demi tinta dan kalam) dan jika huruf tersebut merupakan suatu tanda dengan berubahnya dan jar-nya, atau tidak berubah dan tidak terbukanya untuk tanda dan ta'nis-nya, dan demikian pula jika ditafsirkan dengan al-h\}ut (ikan): adapun maksud nun yakni pedang, atau dijadikan huruf itu tanda dengan maksud yang menantang. Diartikan pula dengan papan atau lembaran dari cahaya atau emas, sungai di surga dan sebagainya. Bersumpah dengan kalam merupakan pengaguman ( Ia $^{\prime}$ \} $\mathrm{im}$ ) kepada diriNya atas ciptaan dan penyelesaian-Nya dari petunjuk-petunjuk atas hikmah yang agung".

Atas dasar pernyataan tersebut, secara jelas dapat dipahami bahwa huruf nun yang ada pada awal surah al-Qalam merupakan sumpah Allah yang bersifat tantangan kepada orang yang meragukan atas ciptaan-Nya. Penjelasan tersebut kemudian dikuatkan oleh al-Zamakhsyari dengan menjelaskan penggalan ayat setelah menjelaskan makna nun, dengan memahami bahwa penggalan ayat tersebut mengandung makna pengagungan Allah atas diri-Nya yang mampu mencipta dan menyelesaikannya, demikian menurut al-Zamakhsyari.

\section{Penafsiran Al-Zamakhsyari Terhadap Ayat-Ayat Tajassum}

Selain menjelaskan huruf-hurf terpotong yang terdapat di awal surah, Zamakhsyari tidak luput menjelaskan makna ayat-ayat tajassum, seperti kata: (a)Istawa 'ala al-'Arsyi (استوى على (العرش) dalam Al-Qur'an. Dalam menafsirkan kata istiwa 'ala al-'Arsy yang terdapat dalam beberapa surah, al-Zamakhsyari hanya menjelaskan QS Taha/20: 5 secara jelas. Baginya kata istawa 'ala al-'Arsy secara bahasa bermakna tempat tidur bagi seorang raja atau yang terkait dengannya, namun dalam penggunaannya pada ayat ini, menurutnya merupakan kinayah sebagaimana ketika seseorang berkata istawa fulanun 'ala al-'Arsy (polan berada di atas Arsy), pada dasarnya mereka tidak duduk dan memang tidak akan duduk namun penggunaan bahasa tersebut merupakan ungkapan ekspektasi (pengharapan). Penggunaan bahasa kinaya tersebut selain bermakna ekspektasi pun juga bertujuan untuk kemahsyuran atau kepopuleran. Hal itu bisa dilihat dalam pernyataanya:

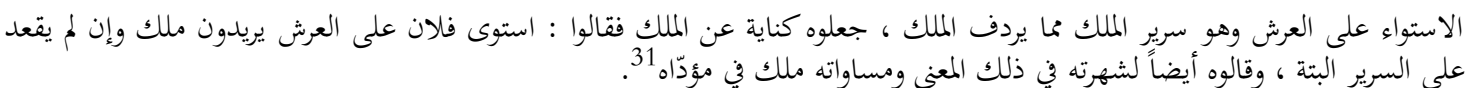

"Istiwa 'ala al-'Arsy merupakan singgasana raja dan apa yang terkait dengannya, dijadikannya setara dengan raja. Sebagaimana ketika orang-orang berkata: si pulan duduk di atas singgasana, maksudnya mereka menginginkannya raja (menjadi raja), dan sebenarnya si polan sama sekali tidak duduk di atas singgasana itu, makna lain kata tersebut ialah kepupuleran dan persamaan dengan raja dalam memimpin".

Penjelasan di atas menunjukkan bahwa al-Zamakhsyari memahami kata Istawa 'ala al-'Arsy merupakan bahasa kinaya, dimana kata tersebut digunakan oleh Allah untuk menggambarkan kebesaran-Nya dan kekuasaan-Nya sebagai penguasa mutlak. Bahkan penggunaan bahasa kinaya tersebut menggambarkan kepada makhluk-Nya mengenai kepemimpinan Allah yang absolut sebagaimana seorang raja kepada bawahannya atau budaknya. Penjelasan tersebut

${ }^{30} \mathrm{Al}-Z$ amakhsyari, al-Kasysyaf, Juz IV, h. 435.

${ }^{31}$ Al-Zamakhsyari, al-Kasysyaf, Juz III\, h. 48. 
sebenarnya cukup beralasan mengingat kata Istawa 'ala al- 'Arsy umumnya digunakan setelah Allah mengemukakan mengenai penciptaan langit dan bumi yang kemudian diikuti oleh masa penciptaannya yakni enam masa.

Tampak pula bahwa al-Zamakhsyari dalam penjelasannya begitu ingin "menjauhkan" Allah dari apa-apa yang terkait dengan materi atau sesuatu yang terbatas. Dalam penjelasannya pada ayat yang lain, ia begitu berusaha memalingkan makna ayat demi mendapatkan makna yang sesuai menurutnya, seperti ketika menjelaskan mengenai kemampuan manusia melihat Allah di hari kemudian. Menurutnya hal itu tidak mungkin terjadi karena bagaimana mungkin sesuatu yang tidak terbatas bisa dilihat oleh yang terbatas. Begitupun dalam ayat ini, dia memahami sebagai bahasa kinaya, karena Allah tidak berada pada suatu tempat sebagaimana yang tampak dalam teks ayat tersebut. Keberadaan Allah di suatu tempat berarti menggambarkan keterbatasan-Nya. Oleh sebab itu dengan jalan pena'wilan ia memahami ayat tersebut bermakna kinaya sebagai gambaran yang dapat dicerna oleh akal manusia yang terbatas.

Selain kata istaawa Kata (b) wajh (وجه) yang disifatkan kepada Allah terdapat dalam empat surah tidak luput dari tinjauan al-Zamakhsyari. Kata tersebut terdapat pada QS alRahman/55: 27 "Tetapi wajah Tuhanmu yang memiliki kebesaran dan kemuliaan tetap kekal", QS Al-Baqarah/2: 115 "Dan milik Allah timur dan barat, maka ke mana pun kamu menghadap di sanalah wajah Allah. Sungguh Allah Maha luas, Maha mengetahui", QS alRad/13: 22 "Dan orang-orang yang sabar karena mengharap keridaaan Tuhan-Nya, melaksanakan salat, dan menginfakkan sebagian rezeki yang kami berikan kepada mereka, secara sembunyi atau terang-terangan serta menolak kejahatan dengan kebaikan; orangorang itulah yang mendapat tempat kesudahan (yang baik).

Dalam mejelaskan kata wajh dalam QS al-Rahman/55: و ويبقى وجه ربك ذو الجلال والآكرام ia berkata bahwa kata wajh ialah و وَجْهُ رَبّك : ذاته ، والوجه يعبر به عن الجملة والذات (wajh ialah zat Allah). ${ }^{32}$ Sedangkan dalam menafsirkan kata wajh dalam QS al-Baqarah/2: 115 dia mengemukakan penjelasan yang berbeda. Menurutnya, lafal فثم وجه الله dalam ayat tersebut bermakna arah yang diperintahkan Allah dan yang diridai-Nya. Potongan lafal tersebut menurutnya memberikan isyarat bahwa apa bila kalian dilarang melaksanakan salat di masjid haram atau masjid alAqs \}a maka dijadikan untuk kalian seluruh bumi ini tempat sujud bagimu oleh sebab itu maka salatlah di dalamnya. Penjelasan tersebut dikuatkannya dengan suatu riwayat dari Ibn Abbas yang mengatakan bahwa "ayat ini diturunkan pada salat musafir dan berada di atas tunggangan yang dimana saja bisa mengahadap". Berikut penjelasan lengkapnya:

$$
\begin{aligned}
& \text { ولله المشرق والمغرب, أي: بلاد المشرق والمغرب والأرض كلها لله هو مالكها ومتوليها) فأينما تولوا (ففي أي مكان فعلتم التولية يعني تولية }
\end{aligned}
$$

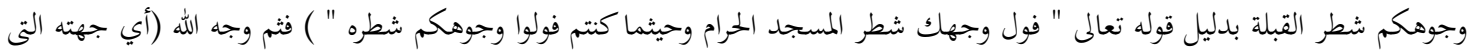

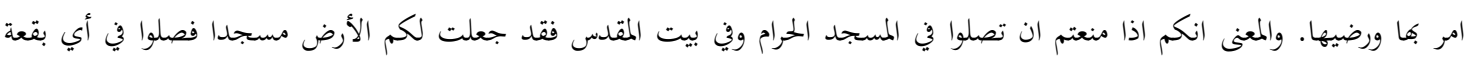

$$
\begin{aligned}
& \text { شئتم من بقاعها. }
\end{aligned}
$$

"Walillahi al-masyriku wa al-magrib yaitu: negara-negara yang ada di timur dan barat dan juga dunia ini semuanya kepunyaan Allah, fa 'ainama tuwallu (tempat dimana engkau menghadap, yakni tempat dimana engkau mengasumsikan mukamu mengarah

\footnotetext{
${ }^{32} \mathrm{Al}-Z a m a k h s y a r i$, al-Kasysyaf, Juz IV, h. 307.

${ }^{33} \mathrm{Al}$-Zamakhsyari, al-Kasysyaf, Juz IV, h. 307.
} 
ke kiblat dengan dalil فول وجهك شطر المسجد... fasamma wajhlilah (yaitu arah yang diperintahkan dan diridai oleh Allah. dan maknanya: apabila engakau dilarang/dicegah untuk melaksanakan salat dimasjid Haram atau di Baitul Maqdis maka Allah menjadikan seluruh bumi ini sebagai tempat sujud bagimu".

Penjelasan yang berbeda ketika menjelaskan lafal yang sama di surah yang berbeda yakni dalam QS al-Rum/30: 38. "Maka berikanlah haknya kepada kerabat juga kepada orangorang miskin dan orang-orang yang dalam perjalanan. Itulah yang lebih baik bagi orangorang yang mencari keridaan Allah. Dan mereka itulah orang-orang beruntung. ${ }^{34}$ Dalam menjelaskan ayat ini al-Zamakhsyari menjelaskan dengan menggandeng lafal sebelumnya yakni yuriduna wajhillah. Rangkaian kata tersebut dimaknainya dengan "mereka bermaksud dengan kebaikan mereka yang dilakukannya hanya karena Allah dengan penuh keikhlasan dan kepastian". Penjelasan tersebut dipilihnya dengan membandingkannya dengan QS alLail/92: 20 yang berbunyi:•الآ ابتغاء وجه ربة الآعلى (Tetapi dia memberikan itu semata-mata karena mencari keridaan Tuhannya yang Maha tinggi). Lafal wajhullah sendiri dalam QS al-Rum di atas dipahaminya sebagai Allah yang bisa berkendak dengan zat-Nya dan otoritas yang dimiliki-Nya. ${ }^{35}$

Kata selanjutnya yang menjadi bagian dari penafsiran al-Zamakhsyari terhatadap ayat tajassum ialah kata (c)yadullah (يد الله kata ini disebutkan sebanyak delapan kali yang disifatkan kepada Allah dalam berbagai surah, antara lain: QS al-Fath/48: 10 "Bahwa orangorang yang berjanji setia kepadamu (Muhammad) sesungguhnya mereka hanya berjanji setia kepada Allah. Tangan Allah di atas tangan-tangan mereka. Maka barang siapa melanggar janji, maka sesungguhnya ia melanggar atas (janji) sendiri; dan barangsiapa menepati janjinya kepada Allah, maka Allah akan memberinya pahala yang besar. ${ }^{36}$ QS Ali 'Imran/ 3: 73. "Katakanlah (Muhammad) sesungguhnya karunia itu di tangan Allah"

Ketika menjelaskan kata yadullah pada beberapa ayat, al-Zamakhsyari mengemukakan interpretasi yang beragam. Misalnya ketika ia menjelaskan makna yadullah pada QS $\mathrm{S}\{\mathrm{ad} / 38: 75$ al-Zamakhsyari berpendapat bahwa kata tersebut menunjukkan bahwa Allah dengan dua tangan-Nya mampu mengerjakan lebih banyak perbuatan, Dia (Allah) menguasai banyak hal yang kamu lakukan atau selainnya, bahkan sampai pada apa yang dilakukan oleh hati. ${ }^{37}$ Dengan pandangan tersebut dapat dipahami bahwa al-Zamakhsyari memahami potongan kata tersebut sebagai kekuatan atau kemampuan Allah.

Penjelasan yang berbeda dikemukakannya ketika menjelaskan QS al-Fath/48: 10. Baginya kata yadullah yang digandengkan dengan kata fauka aidihim (tangan Allah di atas tangan mereka) merupakan keterangan yang menunjukkan bahwa perjanjian bersama dengan rasulullah sama dengan melakukan perjanjian dengan Allah tanpa perbedaan di antara keduanya. Hal itu dipahami oleh al-Zamakhsyari dengan melihat QS al-Nisa/4: 80 يطع الرسول فقد

\footnotetext{
${ }^{34}$ Kementerian Agama RI, al-Qur'an dan Terjemahnya.

${ }^{35} \mathrm{Al}$-Zamakhsyari, al-Kasysyaf, Juz III, h. 442.

${ }^{36}$ Kementerian Agama RI, al-Qur'an dan Terjemahnya.

${ }^{37}$ Al-Zamakhsyari, al-Kasysyaf, Juz III, h. 770.
} 
(barang siapa menaati rasul (Muhammad) maka sungguh ia telah menaati Allah).

Berikut penjelasan singkat beliau:

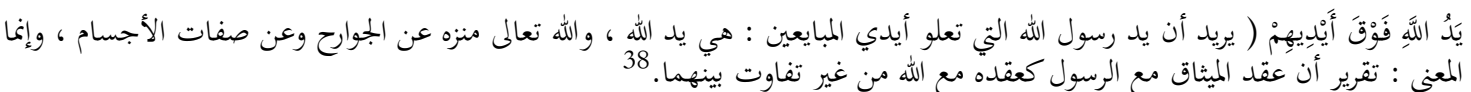

"Yadullaha fauqa aidihim: Dia menginginkan tangan rasulullah berada di atas tangan orang-orang yang melakukan perjanjian, yadullah: Allah menggambarkan dengan anggota badan dan sifat anggota badan, dan maknanya ialah sesungguhnya perjanjian di atas tangan rasulullah sama dengan melakukan perjanjian di atas tangan Allah tanpa perbedaan antara keduanya."

Berbeda halnya ketika al-Zamakhsyari menjelaskan kata biyadika al-Khair (di tangan engkaulah segala kebajikan) dalam QS A $<\mathrm{li}$ 'Imran/3: 26, ia memahami bahwa lafal tersebut menjelaskan mengenai perbuatan Allah atau apa yang dilakukan Allah semuanya baik untuk manusia, baik yang berguna maupun yang tampak membahayakan. Menurutnya semua itu mempunyai hikmah dan kebaikan untuk manusia. Tampak bagi al-Zamakhsyari dalam memahami kata yadun dalam ayat ini cenderung memaknai sebagai tindakan atau perbuatan Allah, dan kata tersebut disandarkan pada kata al-Khair dipahaminya sebagai tindakan atau perbuatan Allah yang selalu baik dan tidak pernah salah meskipun manusia terkadang tidak mampu memahaminya. Ia mengemukakan dalam tafsirnya:

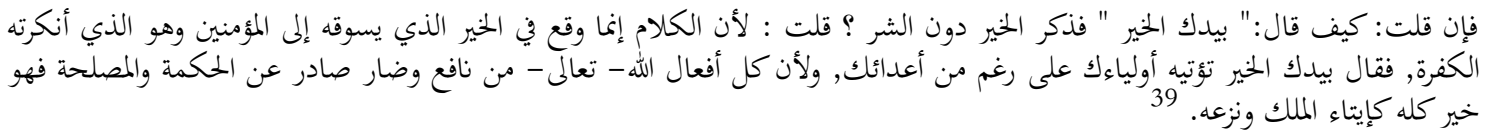

"Jika engkau berkata: bagaimana dengan kata "biyadika al-khair" disebutnya kata alKhair (kebaikan) tanpa al-Syarr (keburukan)? Saya berkata: pernyataan tersebut sesungguhnya dimaksudkan pada al-Khair (kebaikan) yang menyampaikan kepada orang-orang mukmin (yaitu orang-orang yang menjauhkan diri dari kekufuran), lalu berkata di tangan-Mulah segala kebaikan, Engkau memberikannya kebada wali-wali$\mathrm{Mu}$ dan begitupun terhadap musuh-musuh-Mu (orang-orang yang tidak patuh). Sesungguhnya setiap perbuatan Allah itu berguna walaupun hal yang dianggap membahayakan, itu mengandung hikma dan kebaikan. Maka setiap kebaikan berasal dari Allah dan dikendalikan-Nya."

Kata selanjutnya yang dijelaskan al-Zamakhsyari ialah Kata (d) Janbillah (جنب الله) dalam QS al-Sumar/39: 56. "Supaya jangan ada orang yang mengatakan, "alangkah besar penyesalanku atas kelalaianku dalam (menunaikan kewajiban) terhadap Allah, dan sesungguhnya aku termasuk orang-orang yang memperolok-olokkan (agama Allah)" ${ }^{40}$ Al-Zamakhsyari berpandangan mengenai kata $f i$ Janbillah yang terdapat pada ayat tersebut bermakna

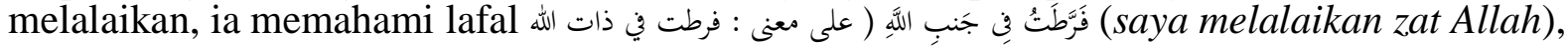
namun dijelaskan dengan detail selanjutnya bahwa melalaikan zat Allah merupakan bahasa

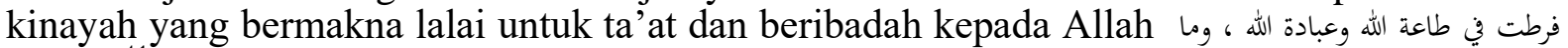
فرطت menjelaskan ayat tersebut.

Selain potongan ayat tersebut, Kata (e)'Ainun (عين) tidak luput dari sorotan ulama Tafsir tersebut, kata ainun (mata) yang disandarkan kepada Allah dalam beberapa surah seperti QS

${ }^{38} \mathrm{Al}-Z a m a k h s y a r i$, al-Kasysyaf, Juz IV, h. 210.

${ }^{39}$ Al-Zamakhsyari, al-Kasysyaf, Juz IV, h. 210.

${ }^{40}$ Kementerian Agama RI, al-Qur'an dan Terjemahnya.

${ }^{41} \mathrm{Al}$-Zamakhsyari, al-Kasysyaf, Juz IV, h. 30. 
T\{aha/20: 39, QS Al-Qamar/54: 14, QS Hud/11: 37 . Dalam penjelasannya ia memaknai kata 'ainun (mata) tersebut dengan pengawasan Allah terhadap nabi Nuh dalam membuat

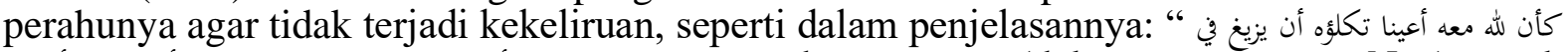
bersamanya (dalam pengawasan-Nya) untuk meluruskan atau membimbing pekerjaannya agar tetap dalam koridor yang benar, atau dalam perbuataanya tidak berbeda antara perbuatan yang satu dengan yang lain dalam penyusunannya". Kata 'ayunina yang terdapat dalam QS al-Sumar/54: 14 tidak dijelaskan oleh al-Zamakhsyari mengenai maknanya secara tersendiri. Intinya adalah kata ainun (mata) dalam ayat di atas ketika menceritakan kisah Nabi Nuh as. Tidaklah sama dengan mata yang dimiliki oleh manusia, karna kata tersebut bermakna majazi bukan hakiki.

Kemudia Kata (f) Shaffa (وجاء ربّك و الملائكة صفا صفا.), dalam QS Al Fajar/89: 22 yang berbunyi "Dan datanglah Tuhanmu sedang malaikat berbaris-baris:. ${ }^{42}$ Dikomentari oleh AlZamakhsyari dengan pandangan berbeda dengan ulama Tafsir pada umumnya. AlZamakhsyari menjelaskan makna kata s\}affa-s\}affa dalam rangkaian ayat tersebut. Menurutnya, kata tersebut bermakna الملائكة كلّ سماء فيسطفون صفا بعض صف محدقين من الجن و الإنس ينزs "malaikat turun dari tiap langit lalu mereka berbaris saf demi saf yang dikelilingi jin dan manusia". ${ }^{43}$ Dengan penjelasan tersebut maka dapat diartikan ayat 22 surah al-Fajr "Dan datanglah Tuhanmu lalu para malaikat berbaris saf demi saf yang dikelilingi oleh jin dan manusia".

Tidak hanya sampai di situ, al-Zamakhsyari juga mengemukakan pandangannya terhadap kata (g) kursi (كرسي), yang ditemukan dalam QS Al-Baqarah/2: 255, berbunyi "Allah, tidak ada Tuhan (yang berhak disembah) selain Dia yang Maha hidup kekal lagi terus menerus mengurus (makhluk-Nya); tidak mengantuk dan tidak tidur. Milik-Nya apa yang di langit dan apa yang di bumi. Tiada yang dapat memberi syafaat di sisi Allah tanpa izin-Nya. Allah mengetahui apa-apa yang di hadapan mereka dan di belakang mereka, dan mereka tidak mengetahui sesuatu apa pun tentang ilmu-Nya melainkan apa yang dikehendaki. Kursi-Nya meliputi langit dan bumi. Dan Dia tidak merasa berat memelihara keduanya, dan Allah Maha tinggi, Maha besar", 44

Al-Zamaksyari memahami bahwa kata kursiyyuhu sebagai kata yang bermakna majazi (kiasan) dan tidak dapat diartikan secara lafz\}i. Penggunaan bahasa majas tersebut menurut al-Zamakhsyari bertujuan untuk mempermudah indra manusia untuk menangkap maknanya. Alasan tersebut dikuatkan dengan logika sederhana bahwa kalau itu bermakna hakiki atau dipahami seperti teksnya ayat itu maka siapa yang duduk dan apakah ada yang membutuhkan duduk "di sana". Oleh sebab itu karena tiadanya yang duduk dan tidak ada yang membutuhkan duduk, maka al-Zamakhsyari berkesimpulan bahwa kata tersebut tidak bermakna hakiki namun hanya bermakna majasi. Selanjutnya ia memahami bahwa makna kata kursiyyuhu dalam ayat itu ialah bermakna ilmu, kekuasaan, kekayaan, dan kepemilikan kesemuanya ada di sisi Allah.

Setelah melihat dan mengamati penafsiran al-Zamakhsyari di atas maka QS al-Baqarah/2: 255 dapat dipahami "Allah, tidak ada Tuhan (yang berhak disembah) selain Dia yang Maha hidup kekal lagi terus menerus mengurus (makhluk-Nya); tidak mengantuk dan tidak tidur. Milik-Nya apa yang dilangit dan apa yang di bumi. Tiada yang dapat memberi syafaat di sisi Allah tanpa izin-Nya. Allah mengetahui apa-apa yang di hadapan mereka dan di belakang

\footnotetext{
${ }^{42}$ Kementerian Agama RI, al-Qur'an dan terjemahnya.

${ }^{43} \mathrm{Al}$-Zamakhsyari, al-Kasysyaf, Juz IV, h. 583.

${ }^{44}$ Kementerian Agama RI, al-Qur'an dan Terjemahnya.
} 
mereka, dan mereka tidak mengetahui sesuatu apa pun tentang ilmu-Nya melainkan apa yang dikehendaki. Ilmu, kekuasaan, dan kekayaan-Nya meliputi langit dan bumi. Dan Dia tidak merasa berat memelihara keduanya, dan Allah Maha tinggi, Maha besar.

Ayat-ayat tersebut dianggap oleh ulama sebagai ayat tajassum atau mutasyabih al-Syifah. Anggapan tersebut berdasar mengingat satu kata (lafal) yang terdapat pada setiap ayat di atas selain disandarkan kepada Allah yang Qadim dalam penggunaanya digunakan pula untuk menunjuk kepada apa yang terkait dengan manusia atau makhluk-Nya yang jelas-jelas baru.

Selain menafsirkan ayat-ayat muqat $t_{j}$ a $^{\prime}$ 'ah dan ayat-ayat tajassum di atas, al-Zamakhsyari juga menafsirkan beberapa ayat yang di anggapnya sebagai ayat-ayat mutasyabihat secara eksplisit. Ayat-ayat tersebut dikemukakannya ketika menjelaskan QS A<li 'Imran/3: 7. Ayatayat tersebut antara lain: QS al-Qiyamah/75: 23, QS al-An'am/6: 103, QS al-A'raf/7: 28, dan QS al-Isra'/17: 16. Uraian-uraian terhadap ayat-ayat tersebut anatara lain:

\section{a. Panjelasan al-Zamakhsyari mengenai kata الى ربها ناظره}

Pada penjelasannya, al-Zamakhsyari menjelaskan kata الى رهما ناظره (kepada Tuhan-nya mereka memandang) pada QS al-Qiyamah mempunyai penafsiran yang berbeda dengan lazimnya penafsiran. Ia memahami bahwa kata tersebut tidaklah bermakna memandang dengan mata kepala, namun kata naz\}irah bermakna التوقع والرجاء (menunggu dan berharap). Penjelasan tersebut dikemukakannya dengan detail di bawah ini:

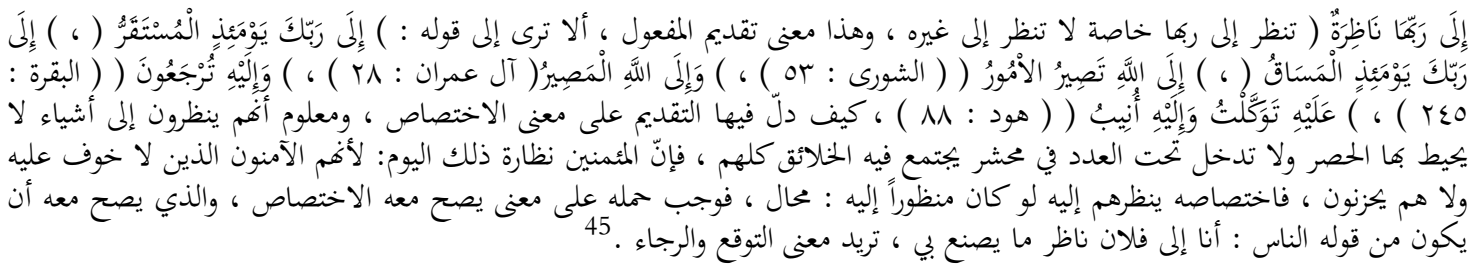

“Ila Rabbiha naz\}irah: memandang kepada Tuhannya secara khusus tidak memandang kepada selainnya, dan maknanya adalah menunjukkan sesuatu yang dilakukan, ... , [karena] bagaimana bisa menunjukkan makna secara khusus (melihat dengan mata kepala) sedangkan diketahui bahwa mereka memandang atas sesuatu yang tidak terbatas dan tidak berbilang pada padang mahsyar yang berkumpul didalamnya seluruh makhluk, sesungguhnya orang-orang mukmin menyaksikan pada hari itu, karena sesungguhnya mereka beriman yang tidak ada ketakutan dan kecemasan bagi mereka, mereka memandang dalam suatu tempat tertentu kepada Tuhannya apabila diharapkan, hal tersebut mustahil atau tidak mungkin terjadi, oleh sebab itu maka wajib memberikan makna yang benar, ..., dan makna yang tepat dengan itu ialah menunggu dan berharap."

Dengan penafsiran yang demikian, maka ayat 22-23 pada surah al-Qiyamah dapat diterjemahkan "dan wajah orang-orang mukmin pada hari itu berseri seri, dan kepada tuhannya mereka menunggu dan berharap". Tampak dalam penafsiran ini begitu dipengaruhi oleh ajaran Mu'tazilah yang memustahilkan manusia bisa melihat Tuhannya baik di dunia maupun di akhirat. Al-Zamakhsyari dalam mendukung argumentasinya, ia mengangkat QS al-An'am/6: 103 yang berbunyi:

${ }^{45}$ Al-Zamakhsyari, al-Kasysyaf, Juz IV, h. 503. 


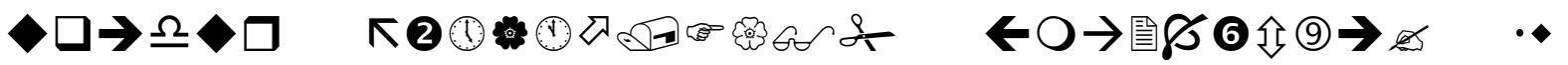

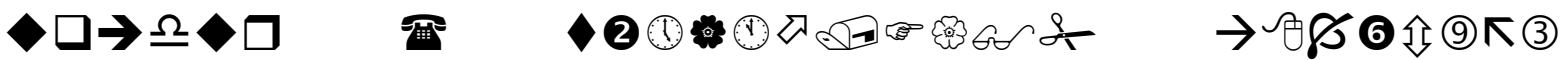

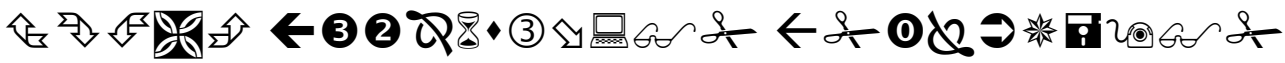

Terjemahnya:

Dia tidak dapat dicapai oleh penglihatan mata, sedang Dia dapat melihat segala penglihatan itu dan Dialah Maha halus, Maha teliti. ${ }^{46}$

Ayat di atas dikategorikannya sebagai ayat mutasyabih. Dalam penjelasannya ia memahami bahwa ketidakmampuan indra untuk menjangkau-Nya karena Dia merupakan satu esensi yang yang dengannya tidak bisa dijangkau oleh inrda penglihatan. Lebih lanjut ia mengatakan bahwa ketidak mampuan indra menjangkaunya karena Dia merupakan zat yang transenden dari penglihatan. Menurutnya penglihatan makhluk tergantung pada yang berasal atau yang mengikutinya seperti jasmani dan kehidupan. ${ }^{47}$ Penafsiran yang demikian itu semakin menunjukkan penolakan al-Zamakhsyari terhadap pandangan yang menganggap bahwa Allah dapat dilihat dengan panca indra manusia.

b. Panjelasan al-Zamaksyari mengenai kata يأمر بالفحشأ

Selain ayat tersebut di atas al-Zamakhsyari pun mengategorikan QS al-A'raf/7: 28 sebagai ayat mutasyabih. Ayat tersebut berbunyi:

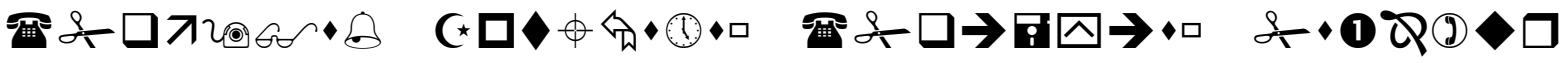

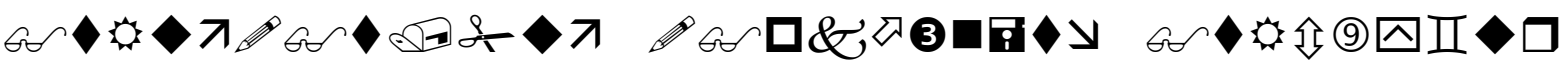

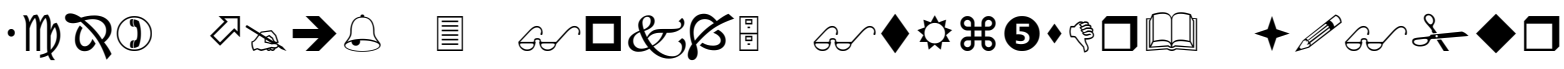

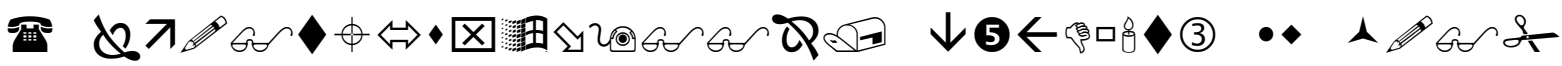 - Go है।

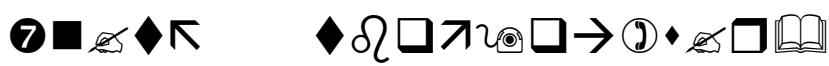 台㩆全}

Terjemahnya:

Dan apabila mereka melakukan perbuatan keji, mereka berkata "kami mendapati nenek moyang kami melakukan yang demikian, dan Allah menyuruh kami mengerjakannya". Katakanlah bahwa Allah tidak pernah menyuruh berbuat keji. Mengapa kamu membicarakan tentang Allah apa yang tidak kamu ketahui. ${ }^{48}$

Ayat di atas dipahami sebagai ayat mutasyabih karena dua amar, yaitu amarna biha dan la ya'muru bi al-fahsya. Menurutnya kata amara yang bermakna menyuruh kepada yang buruk

\footnotetext{
${ }^{46}$ Kementerian Agama RI, al-Qur'an dan Terjemahnya.

${ }^{47}$ Al-Zamakhsyari, al-Kasysyaf, Juz II, h. 51-52.

${ }^{48}$ Kementerian Agama RI, al-Qur'an dan Terjemahnya.
} 
mustahil bagi Allah. Al-Zamakhsyari beranggapan bahwa kata amara yang terdapat dalam ayat ini tidak bermakna hakiki melainkan bermakna majasi. Itu ditegaskan oleh Allah oleh kata la ya'muru bi al-fahsya yang menunjukkan bahwa Allah tidak mungkin menyuruh kepada keburukan dan kesewenang-wenangan. Pandangan tersebut sama dengan pandagan Mu'tazilah yang mengggap Allah tidak menginginkan perbuatan buruk karena akan bertentangan dengan sifat keadilan Tuhan itu sendiri, penjelasan terebut berbeda dengan apa yang dipahami oleh Ahlusunnah yang menganggap bahwa Allah bisa saja melakukannya apabila Dia menghendakinya.

c. Panjelasan al-Zamaksyari mengenai kata فنسقو

Selanjutnya, al-Zamakhsyari memasukkan pula QS al-Isra/17: 16 sebagai golongan ayat mutasyabih. Yang berbunyi:

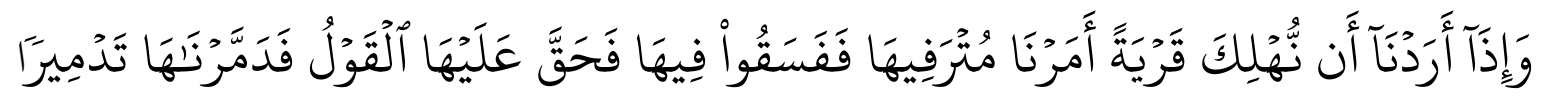

Terjemahnya:

Dan jika Allah hendak membinasakan suatu negeri, maka kami perintahkan kepada orang yang hidup mewah di negeri itu (agar menaati Allah), tetapi bila mereka melakukan kedurhakaan di dalam (negeri) itu, maka sepantasnyalah berlakulah terhadapnya perkataan (hukuman kami), kemudian kami binasakan sama sekali (negeri itu). ${ }^{49}$

Ayat tersebut dikategorikan sebagai ayat mutasyabih oleh al-Zamakhsyari mengingat terdapatnya kata amarna mutrafiha fa fasaku. Menurutnya kata fa fasaku bermakna amarnahum bi al-fiski (menyuruh mereka melakukan kefasikan), dan perintah tersebut hanya merupakan bahasa majasi (kiasan) yang bermakna limpahan nikmat Allah kepada mereka dan kemudian ia menjadikannya sebagai jalan untuk semakin melakukan kedurhakaan dan semakin mengikuti hawa nafsu mereka. sebagaimana dalam penjelasannya:

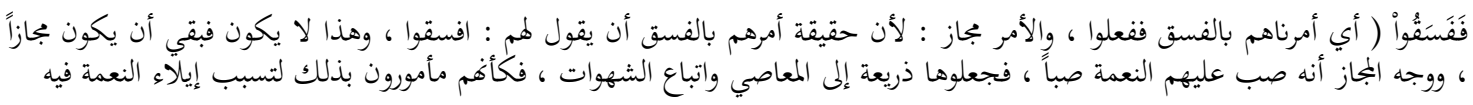

"fafasaku: kami perintahkan kepada mereka untuk melakukan kefasikan lalu mereka melakukannya, dan $a m r$ (perintah) tersebut ialah kiasan: karena sesungguhnya perintah atas mereka untuk melakukan kefasikan sebagaimana yang dikatakan kepada mereka ifsaku, ini tidak bermakna sesungguhnya tetapi merupakan majasi, makna perumpamaan itu ialah sesungguhnya Allah mencurahkan nikmat-Nya sebesarbesarnya kepada mereka, kemudian mereka menjadikan nikmat itu jalan untuk melakukan kemaksiatan dan mengikuti hawa nafsunya, seakan mereka diperintahkan dengan hal itu yang menyebabkan mereka meraup nikmat di dalamnya."

Dengan pena'wilan al-Zamakhsyari yang demikian maka dapat dipahami ayat tersebut "apabila Allah hendak membinasakan satu negeri maka Allah melimpahkan nikmat yang melimpah kepada orang-orang yang hidup mewah di negeri itu sampai mereka menjadikan nikmat itu jalan untuk melakukan maksiat, maka sepantasnyalah berlaku terhadapnya perkataan (hukuman kami), kemudian kami binasakan sama sekali”.

Tampak pada penjelasan al-Zamakhsyari dalam ayat ini begitu ingin menyucikan Allah dari sesuatu yang mestinya hanya terjadi pada manusia bukan pada Allah. Menurutnya perintah Allah kepada orang-orang yang hidup makmur dalam satu negeri untuk melakukan kefasikan

${ }^{49}$ Kementerian Agama RI, al-Qur'an dan Terjemahnya. 
atau kezaliman, itu sangat tidak mungkin dilakuakan oleh Allah karena apa yang Allah lakukan semua untuk kebaikan manusia. ${ }^{50}$

d. Panjelasan al-Zamaksyari mengenai kata ختم

Al-Zamakhsyari menunjukkan perbedaanya sebagai seorang mufasir yang berbeda ketika menjelaskan makna kata khatama didalam QS al Baqarah/2:7.

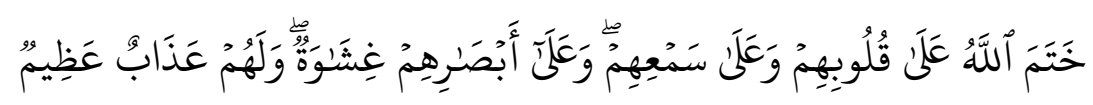

Terjemahnya:

Allah telah mengunci hati dan pendengaran mereka, penglihatan mereka telah tertutup, dan mereka akan mendapatkan azab yang berat. ${ }^{51}$

Ia menjelskan bahwa kata khatamallah dalam ayat itu tidak berarti bahwa Allah yang menutup hati, dan pendengaran mereka akan tetapi setanlah yang menutup itu. Allah hanya memberi potensi kepada setan untuk melakukan semua itu. Hal tersebut tampak dalam penjelasannya:

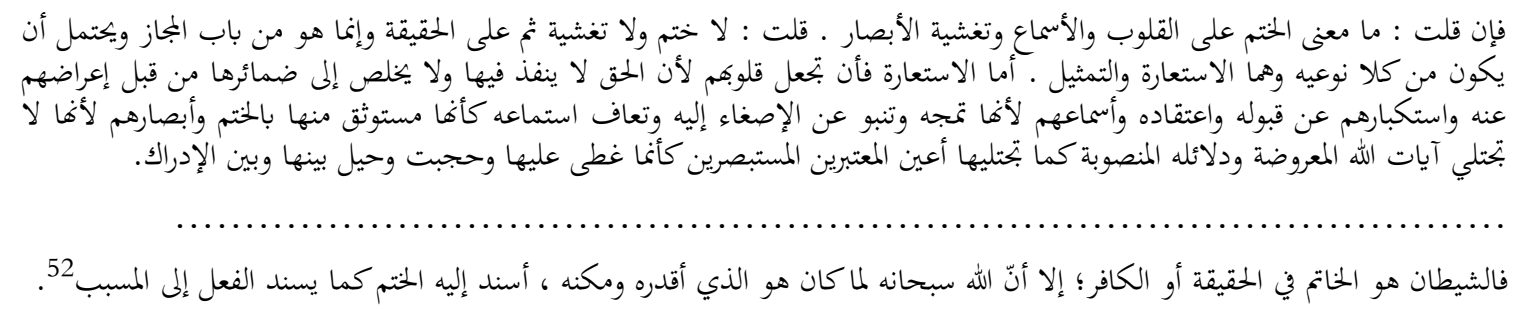

“jika kamu berkata: apa makna mengunci hati, pendengaran dan penglihatan tertutup? Saya berkata: tidak mengunci dan tidak tertutup (dan) disana terdapat hakikat, sesungguhnya itu adalah majas, dan mendukung apa yang tidak esensial, dan keduanya (khatama dan tagsyiyah) menunjuk pada metafora dan penggambaran: adapun metafora tersebut yakni menjadikan hati mereka (terkunci) karena sesungguhnya yang benar itu adalah (Allah) tidak melakukannya (mengunci) dan tidak menutup hatinya sebelum mereka sombong dan berpaling dari-Nya dari perjanjian dan akidahnya, dan tidak pula melakukannya terhadap pendengaran mereka karena menutup pendengaran dan membuka pendengarannya seakan-akan dipastikannya sesuatu kepadanya dengan menguncinya. Dan Allah tidak pula menutup penglihatan mereka karena mata tersebut tidak melihat ayat-ayat Allah yang ditunjukkan dan petunjuk-petunjuk yang dimaksud sebagaimana kelihatannya mata yang memperhatikan seakan-akan tertutup atasnya, menutupi dan "menipu" diantaranya dan di antara pemahaman.

Maka setanlah sebagai pengunci atau penutup secara hakikat atau orang kafir, sedangkan Allah swt hanya memberikan ketetapan (potensi) dan menguasakannya, mendukung kepadanya mengenai penguncian tersbut sebagaimana didukungnya perbuatan oleh sebab."

\footnotetext{
${ }^{50}$ Penjelasan tersebut dapat dilihat pada penjelasannya ketika menjelaskan QS $\mathrm{A}<\mathrm{li}$ 'Imran/3:26 yang telah dibahas sebelumnya.

${ }^{51}$ Kementerian Agama, al-Qur'an dan Terjemahnya.

${ }^{52}$ Al-Zamakhsyari, al-Kasysyaf, Juz I, h. 59.
} 
Menurut al-Zamakhsyari kata khatama (menguci) tidaklah bermakna hikiki namun kata tersebut tidak lain hanya bermkna majasi. Menurutnya penguncian atau penutupan terhadap hati dan pendengaran bukanlah perbuatan Allah melainkan setanlah yang melakukannya. Hanya saja Allah yang memberikan potensi tersebut dan mendukungnya, demikian menurut al-Zamakhsyari.

Penafsiran-penafsiran al-Zamakhsyari terhadap ayat-ayat mutasyabihat cukup menarik perhatian publik, lebik khusus yang menggeluti bidang tafsir. Sebagai tafsir yang lahir dari seorang ahli nahwu sekaligus seorang theolog tentunya mempunyai andil dan pengaruh yang cukup besar terhadap perkembangan tafsir setelahnya. Pemahaman-pemahaman alZamakhsyari terhadap ayat-ayat al-Qur'an turut andil dalam perkembangan tafsir generasi berikutnya. Hal tersebut dapat dilihat pada beberapa karya tafsir yang mengutip argumentasi beliau, baik menjadikannya sebagai pendukung argumentasinya maupun sebagai landasan awal untuk mengritisi pemahaman al-Zamakhsyari.

Pengaruh-pengaruh tersebut dapat dilihat dalam beberapa hal, antara lain.(a)Pengaruh bahasa, penafsiran dengan analisis bahasa yang digunakan al-Zamakhsyari dalam tafsir al-Kasysyaf cukup berpengaruh pada generasi setelahnya. Ignaz goldziher berkata "belum ada seorang penafsir pun segiat al-Zamakhsyari dalam menerangkan kemukjisatan balagah (al-i'jaz albalagi) atas susunan al-Qur'an". ${ }^{33}$ Sisi penafsiran seperti itulah (yang menganalis dengan pendekatan balagah) yang membuat al-Zamakhsyari mendapat keagungan dan pujian dari para lawannya. (b)Pengaruh teologi, sebagai tafsir yang ditulis oleh seorang ulama Mu'tazilah yang dikenal rasional, analisis-analisisnya yang tajam, dan lebih sering mendahulukan akal ketimbang riwayat dapat dikatakan mengilhami pemikir-pemikir Islam setelahnya. Tidak terkecuali pada orang-orang yang berkecimpung dalam bidang tafsir. Pemikirannya terkait dengan kemampuan manusia memahami ayat yang belum jelas penunjukannya menjadi perbincangan di kalangan ulama ulumul Qur'an. Sebagian sepakat dengan hasil pemikirannya sampai ia mengaguminya, sebagian yang lain menolak bahkan tidak segan-segan menganggapnya melenceng dari akidah Islam. (c)Pengaruh cara pandang, cara pandang al-Zamakhsyari yang lebih terbuka dan tidak kaku dalam menafsirkan alQur'an bisa dikatakan berpengaruh besar sampai sekarang ini. Hal itu bisa dilihat pada insan akademik yang sering kali menyandarkan argumentasinya pada ulama tersebut. Penyandaran argumentasi tersebut bukan tidak beralasan, timbulnya animo dan keingin yang tinggi untuk menyelaraskan antara akal dan wahyu membuat para akademisi terkadang memilih cara pandang al-Zamakhsyari sebagai landasan berpikirnya. Cara pandang yang menjadikan akal sebagai alat bedah utama dan menjadikannya menolak riwayat-riwayat yang bertentangan dengan akal, membuatnya digelari sebagai ahlul ra'yi. Al-Zamakhsyari dengan terangterangan menolak riwayat terkait dengan terkenalnya sihir rasulullah dari seorang bangsa Yahudi. Dalam riwayat tersebut diceritakan tentang seorang Yahudi yang meminta Lubaid bin A'tham dan putrinya menyihir Nabi saw. Saat ia kembali dari perjanjian Hudaibiyah. Keduanya lalu melakukannya, keduanya mensipuli Nabi dengan sebelas simpul, lalu meletakkannya dalam sebuah sumur Darwan yang terletak di padang pasir. Kedua sihir itu bekerja dan Muhammad jatuh sakit dan beliau sulit untuk makan dan minum serta gambarangambaran buruk menghantui dirinya. Riwayat tersebut tidak dipahami al-Zamakhsyari sebagai bermakna hakiki namun ia mengemukakan tiga kemungkinan pemaknaan:

1. Bahwa seni menyihir adalah orang harus membuat sampul dengan benang, dan meneluh sesuai dengan seleranya, termasuk menggunakan air liur. Hal ini adalah bagian penting dalam praktek sihir. Ia mempunyai dampak lahir saja, karena hal itu tidak akan berhasil

${ }^{53}$ Ignaz goldziher, Mazhab Tafsir, h. 153. 
kecuali seorang menelan makanan berbahaya atau beracun atau menyentuh langsung bagian wajah yang disihir. Orang yang bodoh melupakan efek membahayakan yang muncul dari makanan itu dan mengalihkannya kepada tukang sihir.

2. Allah menjadikan sihir itu untuk membedakan dan menguji antara orang yang berpegang teguh pada kebenaran dan orang awam yang berpegang pada kebohongan.

3. Bahwa yang dimaksud al-Naffasat dalam surah al-Falaq bukanlah wanita-wanita penyihir, melainkan wanita-wanita yang mempunyai tipu daya atau wanita-wanita yang memfitnah laki-laki dengan memperlihatkan kebaikan-kebaikan mereka. ${ }^{54}$

Alasan-alasan tersebut dikemukakan oleh al-Zamakhsyari terkait dengan dua surah dalam alQur'an yakni QS al-Nas dan QS al-Falaq. Ia menolak anggapan tentang kemungkinan sihir berpengaruh atas diri manusia dan menimbulkan efek buruk terhadapnya. Meskipun anggapan sebagian orang surah al-Falaq dan al-Nas sangat erat kaitannya dengan riwayat tersebut. Cara pandang yang demikian bukan saja terjadi pada al-Zamakhsyari namun sampai dewasa ini penolakan terhadap ayat-ayat yang berbau mistis tidaklah sulit untuk ditemukan. Kaum akademis tampaknya lebih banyak sepakat dengan penafsiran yang selaras dengan akal ketimbang menerima riwayat yang berbau mistis.

\section{Penutup}

Dari uraian dan pembahasan pada bab-bab sebelumnya, maka dapat ditarik beberapa kesimpulan sebagai berikut:

Ayat mutasyabih ialah ayat yang samar penunjukannya, kesamaran tersebut menimbulkaan ketidakjelasan atas dalalah yang dikandungnya. Kesamaran satu ayat dapat terjadi karena tidak lazimnya suatu kata yang digunakan dalam suatu ayat dan dapat pula terjadi karena kosa kata yang digunakan dalam ayat tertentu bersifat multiple sense (mempunyai beberapa makna).

Setelah diteliti secara cermat mengenai pandangan al-Zamakhsyari mengenai eksistensi ayatayat mutasyabihat, dapat dipahami bahwa al-Zamakhsyari mengakui eksistensi ayat-ayat mutasyabihat di dalam al-Qur'an. Pengakuan tersebut dituangkannya dalam mukadimah tafsirnya dan dijelaskannya pada QS A<li 'Imran/3: 7. Bahkan pada ayat tersebut, alZamakhsyari memberikan peluang lebih banyak kepada manusia untuk memahami ayat-ayat mutasyabihat. Baginya ayat-ayat mutasyabihat dapat dipahami oleh manusia namun membutuhkan ketekunan dan pengamatan yang dalam untuk memahami kandungannya. Lebih lanjut ia memahami bahwa di balik kesamaran satu ayat ada hikmah yang banyak untuk manusia. Adapun orang-orang yang melakukan penggalian makna terhadap ayat yang samar tersebut merekalah termasuk orang yang dimuliakan Allah. Hanya saja untuk menentukan beberapa ayat-ayat mutasyabihat dalam al-Qur'an menurut al-Zamakhsyari, satu hal yang sulit dikemukakan karena al-Zamakhsyari sendiri tidak mengemukakannya melainkan hanya mengangkat empat contoh ayat. Namun salah satu indikasi bahwa al-Zamakhsyari mengangggap ayat itu mutasyabih ialah penggunaan bahasanya yang sering menggunakan kata hazla majazun, hazihi kinayah, dan hazla tamsłil.

Penelitian ini pula menunjukkan bahwa al-Zamakhsyari memberikan penafsiran terhadap ayat-ayat mutasyabihat dalam al-Qur'an. Penafsiran diberikannya baik terhadap ayat-ayat

\footnotetext{
${ }^{54}$ Ignaz goldziher, Mazhab Tafsir, h. 174.
} 
muh \}kam maupun ayat-ayat mutasyabihat. Penafsiran dilakukannya kepada sebagian huruf muqat $\{\mathrm{t}\} \mathrm{a}$ 'ah dan sebagian yang lain tidak dijelaskannya. Selain menjelaskan huruf-huruf muqat $\{\mathrm{t}$ \}a'ah ia menjelaskan pula makna beberapa ayat-ayat tajassum. Meskipun terkadang ia hanya menafsirkan satu ayat yang dimana lafal dalam ayat tersebut terdapat pula pada ayat yang lain. Penjelasan al-Zamakhsyari mengenai ayat-ayat muqat $\}$ t $\} a$ 'ah dan tajassum bukan hanya sampai di situ, namun ia mengemukakan penjelasan terhadap ayat-ayat yang dianggapnya sebagai bagian dari ayat-ayat mutasyabihat. 


\section{Daftar Rujukan}

Al-Qur'an al-Karim

Abu Qasim al-Tabrani, Sulaiman bin Ahmad bin Ayyub. Mu'jam al-Kabir, Juz III; [t.t.]: Maktabah al-Ulumu wa al-Hukmu, 1983.

Abu Syuhbah, Muhammad bin Muhammad. Al-Madkhal li Dirasah al-Qur'an al-Karim. Terj. Taufiqurrahman, Studi ulumul Qur'an: Telaah atas Mushaf Ustmani. Bandung: Pustaka Setia, 2003.

Ali, Atabik, Ahmad Zuhdi muhdlor. Al-Asri: Kamus Kontemporer Arab Indonesia; Yogyakarta: Multi Karya Grafika, [t.th.].

Anwar, Rosihon. Ilmu Tafsir. Cet. III; Bandung: CV Pustaka Setia, 2005

Baidan, Nashruddin, Wawasan Baru Ilmu Tafsir. Cet. I; Yogyakarta: Pustaka Pelajar, 2005

------. Metodologi Penafsiran Al-Qur'an. Cet. III; Yogyakarta: Pustaka Pelajar, 2005.

Al-Bāqi, Muhammad Fuad Abd. Mu'jam Mufahras li Alfād\}il Qur'an al-Karim; Indonesia: MaktabaWahlan, t.th.

Bungin, Burhan, ed. Analisis Data Penelitian Kualitatif. Cet. II; Jakarta: Raja Grafindo Persada, 2003.

Al-Darimi, Abdullah bin Abd al-Rahman Abu Muhammad. Sunan al-Darimi, Juz I; Berut: Dar al-kitab al-'Arabi, [t.th.].

Golziher, Ignaz. Mazahibu al-Tafsir al-Islami, Terj. M. Alaika Salamullah, Mazhab Tafsir "dari klasik hingga modern". Terj. Cet III; Yogyakarta: eLSPQ Press, 2006.

Harahap, Syahrini dan Hasan Bakti Nasution, Ensiklopedia Akidah Islam. Cet. II; Jakarta: Kencana Prenada Media Group, 2009.

Al-Haris. Musnad al-Haris, Juz III; [t.t]: Mauqi‘ Jami al-Hadis $\}$, [t.th.].

Al-Hakim al-Naisaburi, Muhammad bin Abdullah Abu Abdillah. Mustadrak 'Ala alSahihain, Juz I; Berut: Dar al-Kitab al-Ilmiah, 1990.

Al-Hanafi al-Haluti, Ismail Huqai bin Mustafa al-Istanbul., Ruhu al-Bayan, Juz I; [t.t.], Dar al-Nasyr, [t.th].

Hadi, Rifki. "Fadail al-Suwar dalam perspektif al-Zamakhsyari (Study atas Kitab alKasysyaf an Hakaik al-Tanzil wa Uyun an Aqawil fi Wujuh al-Ta'wil)", Skripsi (Yogyakarta: Fak. Usuluddin dan Pemikiran UIN Sunan Kali Jaga, 2013.

Hosen, Nadirsyah. "al-Kasysyaf karya al-Zamakhsyari”, Blog Nudirsya Hosen.http://otakkaki.blogspot.co.id/2011/06/al-Kasysyaf-karya-al-Zamakhsyari. Html (14 November 2015).

Ibn Zakariya, Abu Husain Ibn Faris. Mu'jam Maqais al-Lugah, Juz IV; Beirut: Dar al-Fikr, [t.th.].

Ismail ibn Ibrahim ibn al-Mughirah ibn Bardizbah, Abu Abdillah Muhammad ibn, Shahih alBukhari. Juz IV; Berut: Dar Ibn Kasir, 1987.

Al-Juwaini, Mustafa al-S\{awi. Manhaj al-Zamakhsyari fi Tafsir al-Qur'an wa Bayan Ijazih; [t.d.]. 
Kementerian Agama RI, al-Qur'anul Karim wa Tafsiruhu: Muqaddimah Tafsir al-Qur'an.

Kementerian Agama RI, al-Qur'an dan Terjemahnya.

Khalid, Muh. Rusydi. Mengkaji Metode Para Mufassir. Cet. I, Makassar: Alauddin University press, 2012.

Muin Salim, Abd, dkk. Metologi Penelitian Tafsir maudu'I ; Makassar: Al-Zikra, 2011.

Munawwir, Achmad Warison, Muhammad Fairus, Kamus al-Munawwir: Indonesia Arab. Cet. I; Surabaya: Pustaka Progresif, 2007.

Nasution, Harun. Teologi Islam: Aliran-Aliran Sejarah Analisa Perbandingan, edisi kedua. Cet. I; Jakarta: UI Press, 2002.

Narbuko, Cholid dan Abu Achmadi, Metodologi Penelitian . Cet. III; Jakarta: Bumi Aksara, 2001.

Oxford University Press, Oxford Learner's Pocket Dictionary, Fourth Edition, ed. Victoria Bull; China; Oxford University Press, 2008.

Pusat Bahasa Departement pendidikan Nasional, Kamus Besar Bahasa Indonesia, Cet. IV, edisi III; Jakarta: Balai Pustaka, 2005.

Rasyid bin 'Ali Rid\}a, Muhammad. Tafsir al-Qur'an al-Hakim: Tafsir al-Manar, Juz III. Cet. I; Berut: Dar al-Fikr, 2007.

Ristek Muslim, Kamus Arab Indonesia versi 1.11.2. Ristek Muslim, 2012.

Sabry, Muhammad Sadik Melacak. Pola Interpretasi Ayat-ayat Mutasyabih dalam alQur'an: Kajian atas Ayat-ayat Tajassum. Cet. I; Makassar: Alauddin press, 2014.

Sodiqin, Ali. Antropologi al-Qur'an: Model Dialektika Wahyu dan Budaya; Jogjakarta: ArRuzz Media, 2008.

Suparno, "Study Tentang Metode Penafsiran al-Zamakhsyari dalam ayat-ayat Mutasyabihat”, Skripsi. Surabaya: Fak Usuluddin IAIN Sunan Ampel, 1995.

UIN Alauddin Makassar. Pedoman Penulisan Karya Tulis Ilmiah. Cet. I; Makassar: Alauddin Press, 2013.

Umar bin Kaslir al-Quraisi al-Damsyiki, Abu Fada'I Ismail bin. Tafsir al-Qur'an al- 'Az\}im, Juz I. Cet. I; Berut: Maktabah al-Nur al-Ilmiyah, 1991.

Al-Qattan, Manna Khalil. Mabahis $\backslash$ Fi ulum al Quran, terj. Mudzakkir AS, Studi Ilmu-Ilmu Qur'an. Cet. X; Bogor: Litera Antar Nusa, 2007.

Al-Qurtubi, Abu Abdillah Muhammadn bin Ahmad Syamsuddin. al-Jami Ahkami al-Qur'ani , Juz IV; Berut: Dar al-Kitab al-Ilmiyah, 1993.

Quraish Shihab, Muhammad. Mukjizat al-Qur'an: Ditinjau dari Aspek Kebahasaan, Isyarat Ilmiah, dan Pemberitaan gaib. Cet. I; bandung: Mizan Pustaka, 2014.

-------. Kaidah Tafsir: Syarat, Ketentuan, dan Aturan yang Patut Anda Ketahui dalam Memahami ayat-ayat al-Qur'an. Cet. II; Tangerang: Lentera Hati,2013.

Al-Razi, Fakh al-Din. Mafatih al-Gaib, Juz II. Beirut Libanon: Dar al-Fikr, 1993.

Al-Suyuti, Jalaluddin Abdu Rahman. Al-Itqan fi ulum al-Qur'an; Berut: Dar al-Kitab alArabi, 2010. 
Al-Zahabi, Muhammad Husain. Al-Tafsir wa Mufassirun, Juz I; Mesir: Dar al-Kutub alHadis, 1961.

Al-Zamakhsyari al-Khawarizm, Abu Qasim Muhamad bin Umar. al-Kasysyaf an Haqaiki alTanzili wa Uyuni al-Ta'wili Fi Wujuhi al-Ta'wili, Juz I,II,II,IV; Kairo: Dar alHadis, 2012.

Al-Zarkasyi, Badr al-Din Muhammad bin Abdullah. al-Burhan fi ulum al-Qur'an, II; Berut: Dar al-Fikr, 1988.

Al-Zarqani, Muhammad Abdul Az\} \}im,. Manahilul Irfan Fi Ulum al-Qur'an, II. Cet. I; [t.t.]: Dar al-Qutaibah, 1998. 